\title{
Trilobites and inarticulate brachiopods from the Devonian Floresta Formation of Colombia: a review
}

\author{
Pierre Morzadec, Michal Mergl, Carlos Villarroel, Philippe JanVier \& \\ PATRICK R. RACHEBOEUF
}

\begin{abstract}
The study of Devonian Colombian trilobites and inarticulate brachiopods allows to recognize two biostratigraphic levels within the Floresta Formation. The first level, in the lower part of the formation, is late Emsian in age, and yields 14 distinct trilobite taxa, including Colombianaspis carvalhoae gen. et sp. nov. The second one, in the upper part of the formation, is assigned to the Givetian based on the co-occurrence of the genera Dipleura and Greenops; this is the first record of a Givetian age for the upper part of the Floresta Formation. The inarticulate brachiopods collected from the uppermost part of the formation suggest a Givetian age. Inarticulate brachiopods as well as the trilobites show close affinities with the North Eastern Americas Realm, but they also suggest European affinities. The late Emsian occurrence of calmoniids from Colombia is indicative of restricted faunal exchanges with the Malvinokaffric Realm. $\bullet$ Key words: trilobites, inarticulate brachiopods, Devonian, Colombia, biostratigraphy, palaeobiogeography.
\end{abstract}

Morzadec, P., Mergl, M., Villarroel, C., JanVier, P. \& Racheboeuf, P.R. 2015. Trilobites and inarticulate brachiopods from the Devonian Floresta Formation of Colombia: a review. Bulletin of Geosciences 90(2), 331-358 (12 figures). Czech Geological Survey, Prague. ISSN 1214-1119. Manuscript received April 16, 2014; accepted in revised form November 6, 2014; published online February 4, 2015; issued March 23, 2015.

Pierre Morzadec (corresponding author), 17 rue du Hyl, 35510 Cesson-Sévigné, France; pierre.morzadec@wanadoo.fr - Michal Mergl, Department of Biology, Faculty of Education, University of West Bohemia in Pilsen, Klatovská 51, 30619 Pilsen, Czech Republic; mmergl@kbi.zcu.cz•Carlos Villarroel, Universidad Nacional de Colombia, Bogota, Colombia; cmvillaroela@unal.edu.co・Philippe Janvier, UMR 7207 of CNRS (CR2P), Sorbonne Universités, Muséum National d'Histoire Naturelle, CP 38, Paléontologie, 8, rue Buffon, 75231 Paris cedex 05, France; janvier@mnhn.fr - Patrick R. Racheboeuf, Paléontologie, Université Européenne de Bretagne, Université de Bretagne Occidentale, UFR Sciences et Techniques, Paléontologie, 6 Avenue Le Gorgeu, 29238 Brest cedex 3, France and Chemin de Guern Bihan, 29550 Saint-Nic, France; patrick.racheboeuf@sfr.fr

In northwestern South America, Devonian strata outcrop around some of the Precambrian massifs in the northern part of the Cordillera Oriental of Colombia, namely the Quetame, Floresta and Santander massifs, and in the Serranía de Perijá, but also in the Cordillera de Mérida in Venezuela.

In Colombia, the Devonian sequence is over 1,500 m thick. From a lithological point of view, the succession is the same in all the known localities, and represents a sedimentary cycle overlying the Precambrian metasediments and metamorphites. It is covered by Carboniferous and/or Cretaceous. The Devonian succession begins with a conglomeratic level with decreasing gradded-bedding, corresponding to the beginning of the Devonian marine transgression, up to $420 \mathrm{~m}$ thick; it is referred to as the El Tibet Formation in the Floresta area, and Gutiérrez Formation in the Quetame area. The basal lithologic unit is overlain by a $600 \mathrm{~m}$ thick monotonous succession of silts and silstones; this level is highly fossiliferous (brachiopods, bryozans, crinoids, trilobites, ostracodes, corals, molluscs, vertebrates) and is referred to as the Floresta Formation in the eponymous area, or the Portachuelo Formation around Quetame.

The upper part of this succession is over $550 \mathrm{~m}$ thick and consists of an alternating sequence of pinkish to greenish, sandy, silty, and argillaceous levels yielding plant fragments, vertebrate remains, molluscs and ostracodes. In the Floresta area this unit, which corresponds to a regressive event, is referred to as the Cuche Formation, whereas it is known as the Pipiral Formation in the Quetame area (Villarroel in preparation). In other areas, such as the Serranía de Perijá (Forero 1970), and the Santander Massif (Boinet et al. 1986), the fossiliferous Devonian strata have not yet been named. As a whole, the litho- and biofacies strongly suggest that the sediments have been 


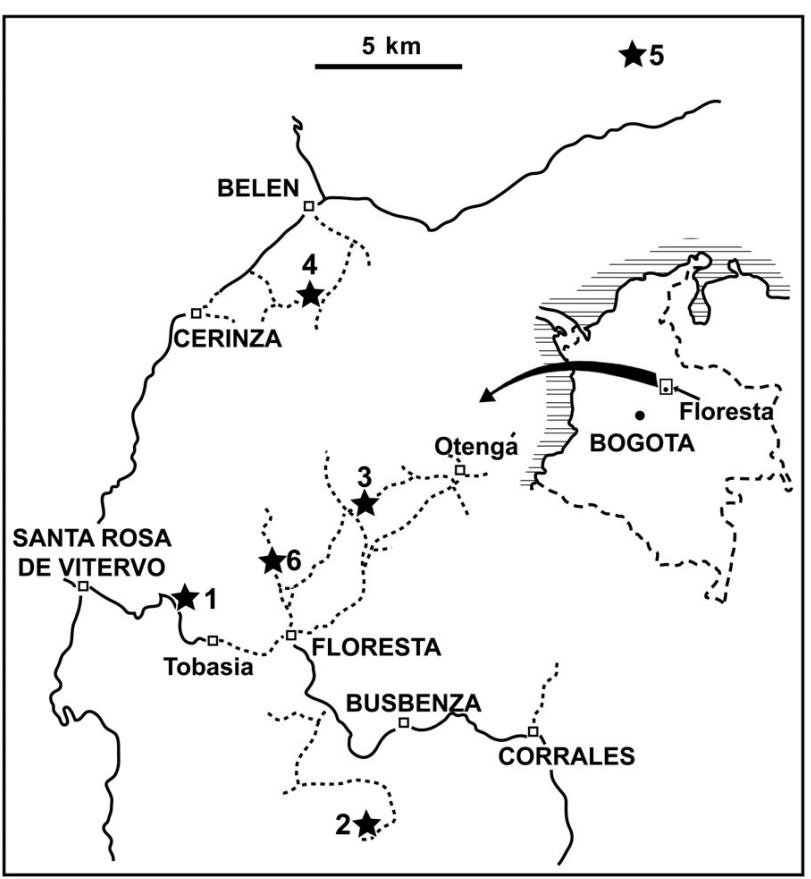

Figure 1. Geographic location of the fossiliferous localities and sections of the Floresta Fm. which provided the specimens. 1 - Quebrada Monticelo (N-NW of Tobasia), 2 - Quebrada Las Pilas (S-SW of Busbanza), 3 - W-SW of Otenga, 4 - Morro Cabezon (E-NE of Cerinza), 5 - Rio Pargua, 6 - N-NW of Floresta (2 km south of Las Cruces).

deposited in a shallow, epicontinental sea, opened towards the north (Barrett 1988) during the Emsian-Frasnian time interval.

Since the mid twentieth century, the Floresta Massif, which is located $125 \mathrm{~km}$ NE of Bogotá in the Boyacá department (Fig. 1), is a key area for the study of the Colombian Devonian fauna and flora of Colombia. Abundant and diverse plants, invertebrates and vertebrates have been described (e.g., Caster 1939, Berry et al. 2000, Janvier \& Villarroel 2000). However, although fossils are abundant and widely distributed in the succession, their preservation is often poor, except in some localities.

Specimens described and illustrated in this paper are reposited in the collection of the Muséum d'Histoire Naturelle de Nantes, France under numbers MHNN.P.082701 to 082772, 082785 (trilobites), and MHNN.P.082773 to 082784,082786 to 082798 (inarticulate brachiopods). They were collected by three of the co-authors. C. Villarroel collected the trilobites from the lower level of the Floresta Formation, whereas P. Janvier \& P.R. Racheboeuf collected the specimens from the upper levels of this formation. Trilobite specimens are decalcified and variably distorted by tectonics. Only few specimens are available for each taxon and exoskeletons are most often disarticulated. Consequently, reliable identification was impossible for some forms which have been left in open nomenclature.

\section{Stratigraphy (P. Morzadec)}

Two distinct stratigraphic levels have been identified in the Floresta Formation, both are characterized by their markedly different lithofacies and faunal contents.

In the Quebrada Monticelo section (Fig. 2A), the lower part of the Floresta Formation consists of alternating shales and silts with numerous levels of coquinas yielding an abundant and diverse fauna that comprises bryozoans, tabulate corals, brachiopods, crinoids, trilobites and ostracods. Trilobites have been collected from beds 8 to 11 , i.e. in a 3 meters thick interval (Fig. 2A). Three isolated fossiliferous localities, namely Morro Cabezon (E-NE of Cerinza, Fig. 1-4), W-SW of Otenga (Fig. 1-3), and the Rio Pargua section (Figs 1-5, 3) belong to the same time interval.

In the Las Pilas section (Figs 1-2, 2) trilobites were collected from the upper part of the Floresta Formation, in small sandy lenses intercalated in silts (bed 1, Fig. 2B), below the concretion level which yields the inarticulate brachiopod fauna; trilobite remains are disarticulated, and represented by small forms associated with rare brachiopods, crinoids and tentaculitids. The inarticulate brachiopods have only been collected from the upper part of the Las Pilas section, about $50 \mathrm{~m}$ above the trilobites level (bed 3, Fig. 2B) in siliceous concretions intercalated within grey to black silts. They are associated with undeterminable bivalve molluscs. This brachiopod fauna is indicative of a Givetian age.

The lower level provided us with 14 trilobite species preserved either in the silty layers, or in the decalcified coquinas that have yielded abundant bryozoans and brachiopods. Among the 14 species, Cordania gasepiu is known from the Grande Grève Limestones, Upper Gaspé Limestone in Québec (Lespérance \& Sheehan 1988, p. 1441). Anchiopsis armatus occurs in the Schoharie Grit (late Emsian, serotinus Zone) of the Schoharie area, New York State. Lespérance \& Bourque (1971, p. 204) recorded the species from the Grande Grève Formation in Québec. The genus Coronura is recorded from the Emsian-Eifelian of North America (Holloway \& Carvalho 2010, p. 73). According to Lespérance (1975, p. 122), Coronura lessepsensis from the Grande Grève Formation (Etymothyris Zone, Emsian of Gaspé) is only known from its pygidium. Clarke (1901) described Synphoria stemmata from the Oriskany Formation of the Becraft Mountain, New York, whereas Lespérance \& Bourque (1971, p. 196) mentionned the species in the Oriskany Formation in Virginia and in the Bois Blanc Formation of Michigan (late Emsian, serotinus Zone). According to Eldredge (1973) Viaphacops cristata sensu lato is mainly known from the Grande Grève Formation (Emsian of Québec), and the Esopus and Schoharie formations (late Emsian of the New York area). The species Belenopyge contusa, as well as the genus Mannopyge, both occur in the 

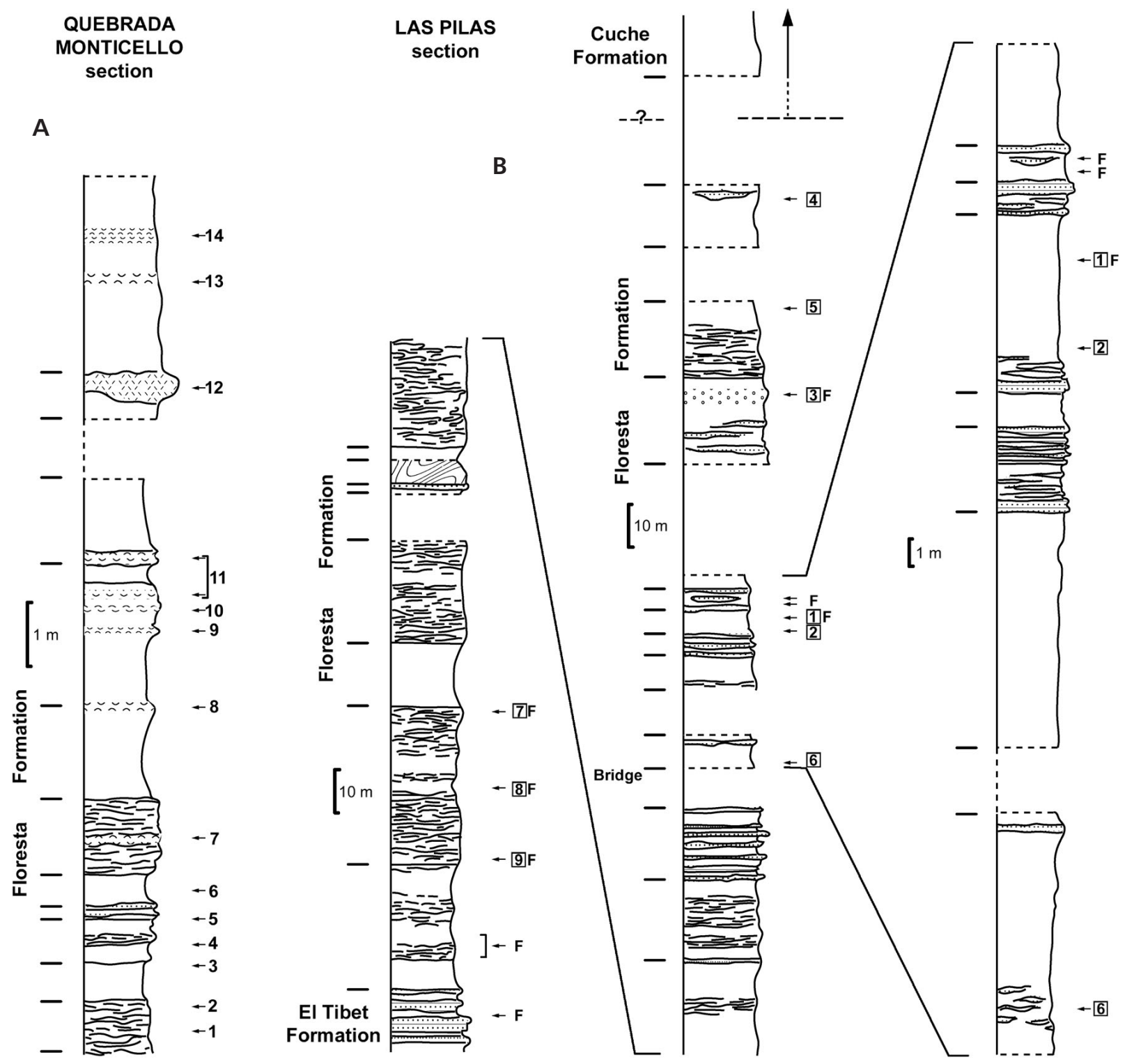

Figure 2. Lithostratigraphic columns of the Quebrada Monticelo (A) and Quebrada Las Pilas (B) sections with localisation of the fossiliferous sampled levels.

Formosa member of the Amherstburg Formation of Ontario, which is assigned to the late Emsian serotinus Zone (Ludvigsen 1987). Consequently, and by comparison to the occurrences from Gaspé, Ontario, and the New York area, these fossiliferous levels of the Floresta Formation are likely to be late Emsian in age (serotinus Zone).

The sandy level that is intercalated within the silts, at the base of the upper half of the Las Pilas section (Fig. 2B, level 1) is mainly composed of thin sandstone beds and fossiliferous sandstone lenses which yield Dipleura cf. dekayi and Greenops cf. grabaui (see systematic section). The genus Dipleura and the species D. dekayi occur in the Givetian of North America, Michigan, Ontario, and the Appalachian range. The genus Greenops is also recorded from the same area where it is restricted to the Givetian of the Appalachian Basin, whilst the species G. grabaui is restricted to the Hamilton Group (Lieberman \& Kloc 1997, p. 96). Although two Colombian forms are still in open nomenclature, they allow to assign a Givetian age to the sandy trilobite level of the Las Pilas section.

\section{Palaeobiogeography (P. Morzadec)}

The occurrence of two distinct trilobite associations in the Floresta Formation is important with regard to the evolution of American palaeogeography during the Devonian. 


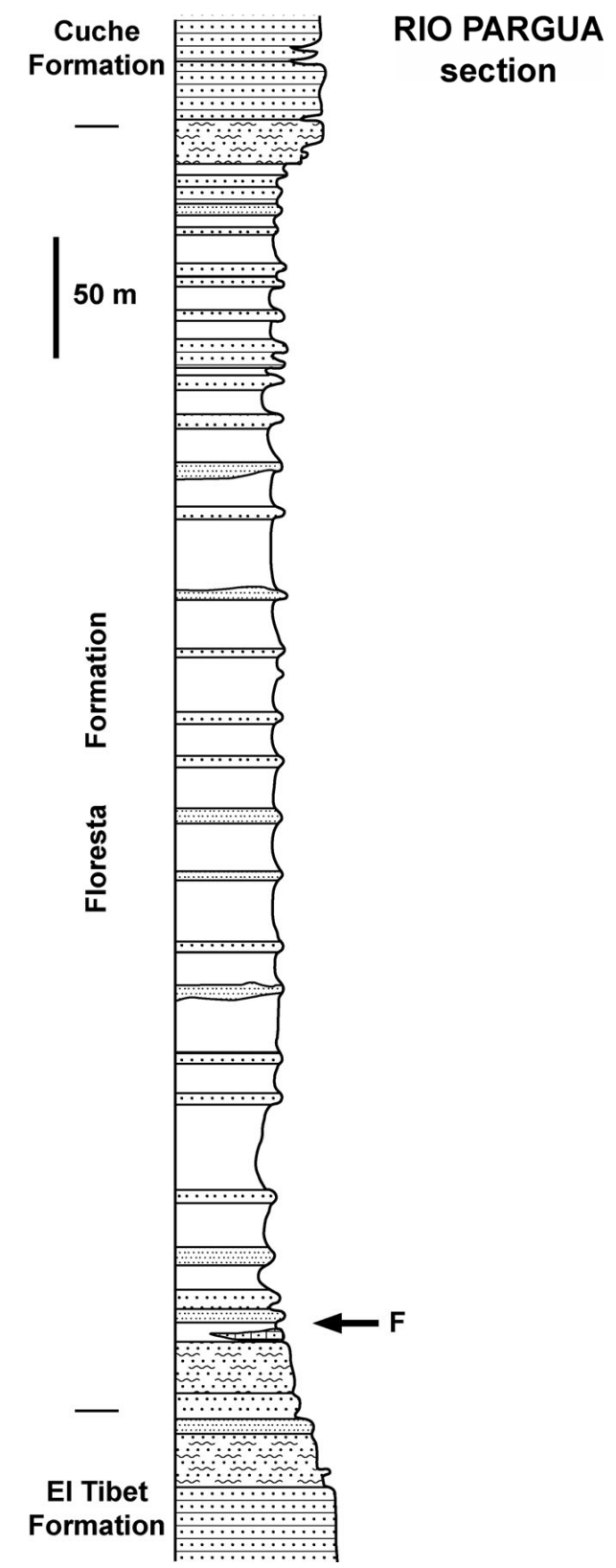

Figure 3. Lithostratigraphic column of the Rio Pargua section with the position of the trilobite level.

The lower trilobite association is typical for the North Eastern Americas Realm. These forms are mainly known from the Appalachian Basin to the Gaspé region of Canada where they have been described in the Emsian Upper Gaspé Limestone (Lespérance \& Sheehan 1988). The genus Cordania Clarke, 1892 (Adrain \& Kloc 1997, p. 709), Viaphacops cristata (Eldredge 1973, p. 314), Anchiopsis armata and Synphoria stemmata (Lespérance \& Bourque 1971), as well as the genus Coronura, are typical early Devonian faunal components of the Appalachian Basin.

The trilobite fauna of the upper level is markedly less diverse. None of the taxa which occur in the lower level are present, and the fauna includes representatives of the genera Dipleura (Homalonotinae), and Greenops (Asteropyginae). However, this fauna exhibits the same North American affinities.

These two trilobite associations imply extensive faunal exchanges between the North Eastern Americas Realm (NEAR), and Colombia. Obviously, the faunal exchanges were better marked during the Emsian than in Givetian times, as suggested by the higher faunal diversity. The different lithologies of the sequences, carbonaceous deposits in the Appalachian Basin, and silty (and locally sandy) deposits in Colombia, may have influenced the geographic distribution of taxa. The small-sized Givetian specimens from Colombia may reflect this environmental factor.

The strong similarities between the faunas of the Floresta Formation and that of North America reflect the conclusions drawn by Morales (1965, p. 73), mainly from the brachiopod faunas. Close affinities with the Middle Devonian of Venezuela have also been established, based on the occurrence of the genera Viaphacops and Greenops (Carvalho \& Moody 2000). Colombia and Venezuela were most probably very close to each other geographically, and had strong faunal relationships with the NEAR (Cooper 1982, p. 164).

Most importantly, only few genera, and none of the species listed from Colombia, are known to occur in the South American Malvinokaffric Realm, especially in Bolivia where a rich and diverse trilobite fauna has been described (Kozlowski 1923; Wolfart 1968; Eldredge \& Branisa 1980; Holloway \& Carvalho 2009, 2010). On the contrary, none of the Malvinokaffric species were found in Colombia. These observations agree with Eldredge \& Ormiston's (1979, p. 148) who studied some faunal components from the Floresta Formation.

Only the genera Dipleura, Viaphacops, Belenopyge, and Kettneraspis and some rare calmonids are common to both domains. The homalonotid genus Dipleura has a large geographic distribution, since it occurs also in Africa and Europe, is therefore not unique to any of these biogeographic domains. The same applies to the genera Viaphacops, Belenopyge and Kettneraspis which show a relatively cosmopolitan distribution (Ramsköld \& Chatterton 1991, p. 357; Thomas \& Holloway 1988, p. 225).

The trilobite faunas suggest that a palaeobiogeographic barrier existed between the North-Eastern Americas Realm, including Venezuela and Colombia, and the Malvinokaffric Realm during the Devonian, as previously presented by, e.g., Barrett (1988), Barrett \& Isaacson (1988), Johnson (1970), and Ormiston (1972). However, faunal exchanges were possible between these two domains, as suggested by Carvalho \& Fonseca (2007, p. 10), and Colombia may have been on the dispersion route between these domains (Holloway \& Carvalho 2010, p. 74). 
In the Late Emsian of Colombia, the occurrence of a form close to the genus Tarijactinoides, a calmoniid known from the Late Lochkovian-Early Pragian Scaphocoelia Zone of Bolivia and from the Talacasto Formation of Argentina (Vaccari et al. 1994), strongly suggests such biogeographic relations. These are further supported by the occurrence of the calmoniid Colombianaspis carvalhoae gen. et sp. nov. in Colombia, the family Calmoniidae being know from Bolivia, Argentina, Brazil, South Africa. Similarly, the subfamily Synphoriinae, which is typical for the Early and Middle Devonian of the NEAR, has representatives both in Colombia and Bolivia (Holloway \& Carvalho 2010). It is worth nothing here that none of these species is hitherto known from the Devonian of Europe and North Africa. Only cosmopolitan genera such as Dipleura, Greenops, Belenopyge and Kettneraspis occur in these distinct biogeographic domains but they are represented by different species.

\section{Systematic palaeontology}

\section{Inarticulate brachiopods (M. Mergl)}

A small sample of lingulate brachiopods has been collected in the upper part of the Las Pilas section, in the uppermost part of the Floresta Formation, about 30 m below the boundary with the overlying Cuche Formation. The lingulate brachiopods co-occur with rare bivalve molluscs without any articulate brachiopod. Apart from the dominant brachiopod genus, three lingulid brachiopods have been recorded, but only two of them are identified at the generic level, namely Schizobolus and Barroisella; the remaining species (Tarutiglossa?) is more restricted quantitatively and qualitatively (preservation). This assemblage indicates a moderate diversity of the lingulate brachiopod fauna.

Records of the Devonian lingulids in South America are rather scarce. Kayser (1897) described Lingula (Dignomia) subalveata from Argentina, which he compared with L. alveata (Hall, 1863). In a more comprehensive paper Clarke (1913) reported five lingulids from the Devonian of the Parana Basin of Brasil. Some have been subsequently referred to Dignomia Hall, 1871 by Copper (1977). Boucot et al. (2001) noted the presence of Lingula sp. cf. Lingula lepta Clarke, 1913 from the Parecis Basin of Brasil. Recent papers (Bosetti 1989; Bosetti \& Quadros 1996; Bosetti et al. 2011; Zabini et al. 2007, 2010) deals mostly with variation of shell morphology, taphonomy and taphofacies of lingulid brachiopods of the Paraná Basin of Brasil; the lingulids observed here more likely belong to Dignomia (Zabini et al. 2007).

Abbreviations. - Wsh - shell width; Lsh - shell length.
Class Lingulata Goryansky \& Popov, 1985

Order Lingulida Waagen, 1885

Superfamily Linguloidea Menke, 1828

Family Lingulidae Menke, 1828

\section{Genus Barroisella Hall \& Clarke, 1892}

Type species. - Barroisella campbeli Cooper, 1942; Upper Devonian, Indiana, U.S.A.

\section{Barroisella sp.}

Figure 4A-E

Material. - Two ventral valves (internal and external moulds; MHNN.P.082773-082774); one incomplete dorsal valve (MHNN.P.082775), and an external mould of a small dorsal valve (MHNN.P.082776).

Description. - The shell is thin-walled, biconvex, with the largest specimen $12 \mathrm{~mm}$ long. The ventral valve is elongate, widest at the anterior third and having an evenly rounded anterior margin and an acute posterior margin. The apical angle is $c a 80^{\circ}$. Lsh/Wsh ratio is 1.5 . The valve is weakly convex at the mid-valve, having a more vaulted transverse profile near the apex. The ventral valve interior shows a weakly impressed rhomboidal visceral area extending to the mid-valve. Propareas are unknown. A pair of weakly diverging ridges is distinct at mid-valve. The dorsal valve is poorly documented and is characterized by an elongate-oval outline with a rounded posterior margin. The shell exterior has a distinct ornamentation of broad regular growth bands with superimposed concentric wavy lines. These lines are rather uniform in a size, $c a 50 \mu \mathrm{m}$ wide, numbering 10-12 per $1 \mathrm{~mm}$ anteromedially. Their size and density decreases laterally, depending on the width of the growth bands. Therefore, the lines are finer and more densely packed in the posterolateral shell sectors than in the median part of the shell.

Remarks. - A pair of prominent divergent ridges in the ventral interior and fine raised wavy concentric fila characterizes the shells of Barroisella sp. These long ridges on the ventral visceral area that run parallel to the pedicle nerve impressions are well documented in other species of Barroisella Hall \& Clarke, 1892. However, details of the ventral interarea are unknown because beaks have been broken off in both available specimens before fossilisation. Barroisella is described from the late Middle and early Upper Devonian of the eastern United States (Hall \& Clarke 1892, Cooper \& Dutro 1982) and from the Frasnian and Famennian of Poland (Baliński 1979, 1995).

Our specimens are most similar to the specimens of Barroisella campbeli Cooper, 1942 illustrated by Holmer 
\& Popov (2000). However, the type specimens have anterior lateral muscles scars clearly impressed, whereas the Colombian specimens have faint impressions of almost all muscle scars. The Famennian specimens referred to B. campbeli by Baliński (1995) have a more elongately elliptical shell outline and may represent a separate species. Paired pedicle nerve supporting ridges on the visceral area are also developed in Langella Méndes, 1961, from the Carboniferous of eastern South America (Méndes 1961), and in Argentiella Archbold et al., 2005, from the early Permian of Argentina (Archbold et al. 2005). Unfortunately, there are not sufficient data on the external microornament of these genera to elucidate their phylogenetic relationships.

Barroisella, Langella, and Argentiella and also the present specimens have a similar outline with evenly rounded anterior margin and maximum width anterior to the mid-valve. Although the taxonomic significance of the outline is restricted, these outlines probably indicate a seminfaunal rather than deeply infaunal mode of life that is characteristic of parallel-sided burrowing lingulids, i.e. Lingula Bruguière, 1797, Glottidia Dall, 1870, Semilingula Popov in Egorov \& Popov, 1990 and Dignomia Hall, 1871.

\section{Tarutiglossa Havlíček, 1984}

Type species. - Tarutiglossa platyfaba Havlíček, 1984; Famennian, Libya.

\section{Tarutiglossa? sp.}

Figure 4F-I

Material. - Two external moulds of the dorsal valve (MHNN.P.082777-082778), and one internal mould of the dorsal valve (MHNN.P.082779).

Description. - The shell is subrectangular, $12 \mathrm{~mm}$ long, with well-rounded posterior margin, almost subparallel lateral margins and a weakly curved to almost straight anterior margin. Lsh/Wsh ratio is 1.3. The valve is posteriorly subcarinate in transverse profile, anteriorly becoming evenly and weakly convex. Maximum height $(1.5 \mathrm{~mm})$ is placed posteromedially. Posterolateral parts of the shell are clearly depressed. The apex is supramarginal, raised above the posterior margin by a low, steeply anacline slope. The dorsal pseudointerarea is very short, undivided. The dorsal valve interior has a well-defined visceral platform, extending over $30 \%$ of the valve length and occupying some $40 \%$ of the valve width. Large central scars are posterolaterally associated with less distinct muscle scars. A reverse $\mathrm{V}$-shaped umbonal muscle scar is placed at the bottom of the umbonal chamber. The shell ornamentation consists of subdued regular growth fila. Flanks bear oblique asymmetrical terrace lines, with a frequency of $70 \mu \mathrm{m}$ apart. These lines are more regular anteriorly, with steeper slopes facing anteromedially. Triangular median shell sector almost smooth, always lacking the terrace lines.

Remarks. - The restricted material prevents generic identification. The absence of any plate in the dorsal pseudointerarea and the smooth exterior are consistent with the attribution of shells to the Lingulidae Menke, 1828. The present specimens show similarity with Tarutiglossa Havlíček, 1984 from the Famennian of Libya, but this genus lacks any traces of the terrace lines. The allocation of Tarutiglossa to the Pseudolingulidae Holmer, 1991 is uncertain; the genus probably belongs to true lingulids. The post-Devonian true lingulids (Lingula Bruguière, 1797, Lingularia Biernat \& Emig, 1993, Semilingula Popov, in Egorov \& Popov, 1990) have a large, anteriorly extended dorsal visceral area that is comparatively shorter in the Colombian material.

Superfamily Discinoidea Gray, 1840

Family Trematidae Schuchert, 1893

\section{Genus Schizobolus Ulrich, 1886}

Type species. - Lingula concentrica (Vanuxem, 1842); Middle Devonian, Tennessee, USA.

Schizobolus pilasiensis sp. nov.

Figure 5A-N

Holotype. - Dorsal valve figured in Fig. 5A, J, K, M, MHNN.P.082780.

Paratype. - Ventral valve figured in Fig. 5D, E, I, MHNN.P.082783.

Etymology. - After the Las Pilas section, type locality.

Type locality. - Upper part of the Floresta Formation in the Las Pilas section.

Type horizon. - Givetian, Floresta Formation, upper part.

Material. - Eight dorsal and ten ventral valves (MHNN.P.082780-082784, 082786-082798) and several fragments, all preserved as undeformed internal and external moulds in siliceous concretions.

Diagnosis. - Schizobolus with subtriangular outline and concentric rugellate ornementation. 


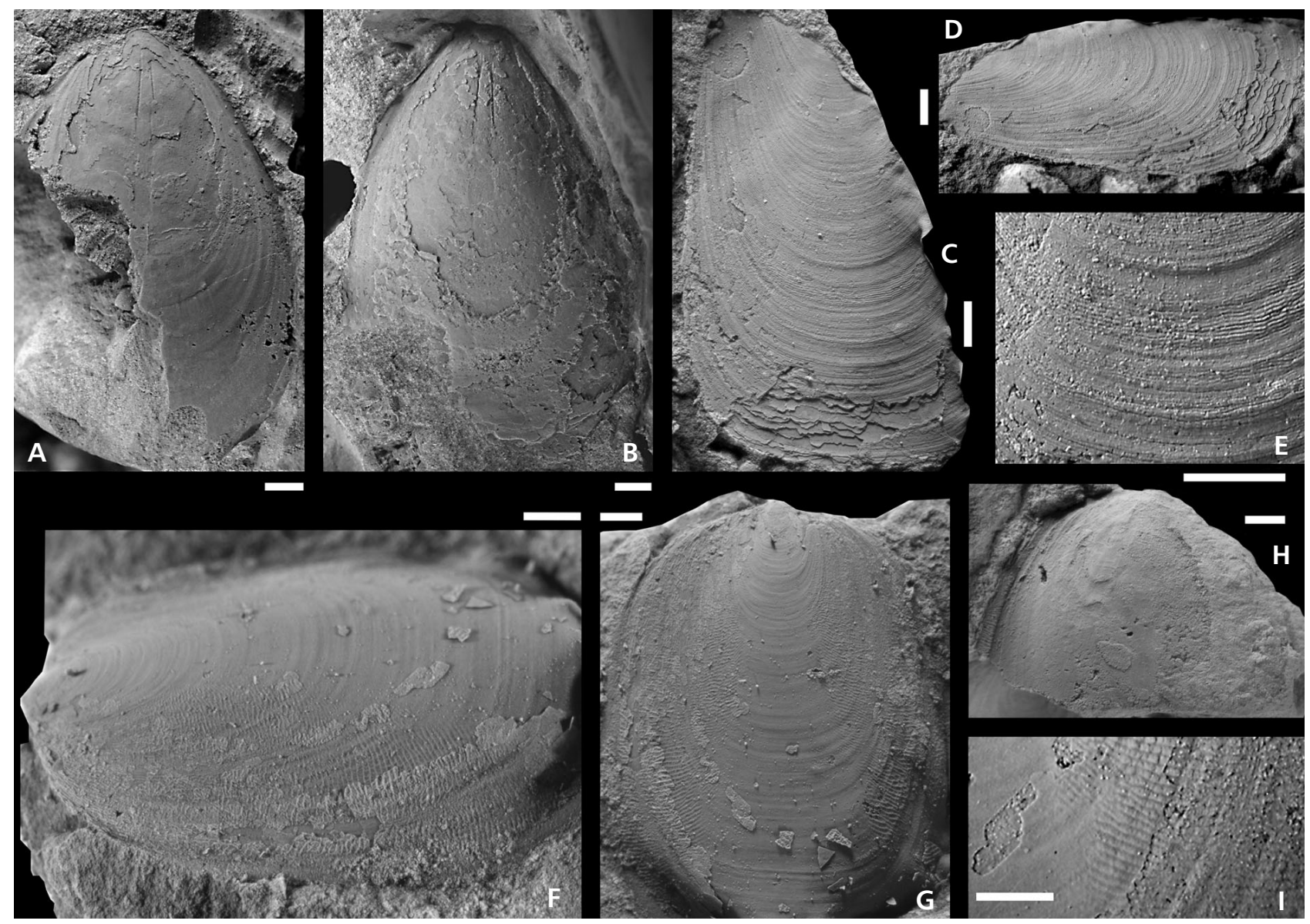

Figure 4. A-E-Barroisella sp. Upper part of the Floresta Formation, Las Pilas section, Givetian. • A, C-E - internal mould of the ventral valve (A), latex casts of exterior showing ornament (C), shell convexity (D) and microornament (E), MHNN.P.082773. $\bullet$ B - internal mould of the ventral valve), MHNN.P.082774. • F-I - Tarutiglossa? sp. Upper part of the Floresta Formation of Las Pilas section, Givetian. • F, G, I - dorsal valve, latex cast of external mould in oblique (F) and dorsal (G) views, and detail of terrace lines (I), MHNN.P.082777; H - dorsal valve, internal mould with muscle scars, MHNN.P.082778. Bar equals $1 \mathrm{~mm}$.

Description. - The shell is thin-walled, subtriangular to subpentagonal in outline, rectimarginate, $7.2 \mathrm{~mm}$ long for the largest specimen. The dorsal valve is widest anterior to the midvalve, with Lsh/Wsh 0.97 to $1.02(\mathrm{n}=4)$. The apex is submarginal. The anterior margin and posterolateral margins are weakly curved. A narrow median part of the posterior margin is almost straight. Lateral margins are most curved anterolaterally. The valve is moderately convex in lateral profile with maximum convexity at the mid-valve. The anterior slope is gently convex and flattened. The posterior slope is steep and slightly concave in an axial profile. The transverse profile is moderately convex having depressed median part. The visceral area is weakly impressed. Two pairs of small muscle scars posterolaterally flank the visceral area. Central muscle scars are oblique, large, extending to almost mid-valve. The vascular system is unknown.

The ventral valve has similar outline and convexity as the dorsal valve except for a more depressed median sector of the valve. The pedicle notch is small, triangular, with posterior end closed by a small pseudointerarea. Propareas are flat, steeply procline, separated by a narrow and deeply concave pedicle groove. The surface of the pseudointerarea is covered by prominent growth lines. The shell ornamentation consists of almost regularly spaced concentric rugellae separated by much broader and flat concentric bands. The rugellae are thin, lamellose, slightly tilted forwards and having height $50 \mu \mathrm{m}$ high maximum. The rugellae are 0.2 to $0.4 \mathrm{~mm}$ apart. Some shells possess only 15 rugellae, but most have 20 to 25 rugellae. Interspaces are broad, flat, covered by a few fine concentric growth fila, about $50 \mu \mathrm{m}$ apart. Microornament unknown due to the poor preservation.

Discussion. - The new species differs from Schizobolus concentricus (Vanuxem, 1842) from the Middle Devonian 
of Poor Valley, Tennessee, USA by a subtriangular shell outline having more convergent posterolateral margins than the type species. The ornament of the new species consists of evenly spaced rugellae, which are not well developed in S. concentricus. Insufficiency of data on shell morphology of the type species prevents a more accurate comparison. On the other hand, the similar shell size, the posteriorly located dorsal apex, the weak shell convexity and the narrowly triangular pedicle notch with a distinct pseudointerarea, which is in the type specimens (Baliński \& Holmer 1999) accentuated by postmortem deformation, indicate the affinity of both species. The Famennian species S. polonicus Baliński \& Holmer, 1999 differs by a smaller listrium and a finer external ornament.

Clarke (1913) reported and illustrated Schizobolus truncatus (Hall, 1863) (= S. concentricus) from the Upper Devonian black shales of Ereré, Parana. The illustrated specimens (Clarke 1913, pl. 25, figs 3, 4) also have a distinct rugellate ornament and may belong $S$. pilasi. Schizobolus truncatus has also been reported from Uruguay (Méndez-Alzola 1938), but both the description and illustrations are poor; illustrated specimen show only general morphology of a discinoid shell.

\section{Conclusions}

Although the collection is limited and the preservation bad, the lingulates from the upper part of the Floresta Formation clearly indicate affinity to the contemporaneous Givetian fauna of the Eastern America Realm and Europe. The presence of Schizobolus in the Floresta Formation in Colombia supports the similarity of the Colombian fauna with that of the North Eastern America Realm (NEAR, Boucot 1975). The genus is known from the Middle Devonian of USA and Poland (Balinski \& Holmer 1999). With the single exception of Clarke's report (1913), the genus Schizobolus is generally unknown among the lingulate fauna from the South American basins, and its report from the $\mathrm{Pa}$ raná Basin of Uruguay by Méndez-Alzola (1938) is questionable. Specimens of Schizobolus from Colombia are undeformed and show better preserved shell morphology, in particular the nature of the ventral pseudointerarea, than the type specimens of the genus (Baliński \& Holmer 1999, fig. 2). Barroisella is known from the Upper Devonian and Lower Carboniferous of North America (New York, New Mexico), Poland, and the Czech Republic (unpublished).
Shell outline and development of distinct pedicle nerve supporting ridges in the ventral valve interior argue for the phylogenetic affinity of Barroisella with Langella and Argentiella. The latter are known from South America in Carboniferous and Permian beds.

\section{Trilobites \\ (P. Morzadec)}

The Devonian of the Floresta area of Colombia (NE of Bogotá, Fig. 1) have inspired several articles dealing mainly with its faunal contents and stratigraphy; see e.g., Caster (1939), Morales (1965), Forero (1970), and Barrett (1988). Unfortunately, the trilobite fauna was never thoroughly investigated in any of these publications, and descriptions as well as illustrations are of poor use; most identifications are often vague, erroneous, or left in open nomenclature.

Caster (1939, pp. 181-182, pl. 14) described and figured four trilobite species from the Floresta Formation namely: Phacops cf. salteri Kozlowski, ?Dalmanites cf. patacamayaënsis Kozlowski, ?Cyphaspis sp., and ?Homalonotus sp. Morales (1965, pp. 89-90, pl. 8) described and/or illustrated five trilobites: Odontopleura callicera (Hall \& Clarke), Phacops salteri Kozlowski, Cryphaeus sp., Proetus sp., and Dalmanites sp., associated with a rich brachiopod fauna. Forero (1970, pl. 1) illustrated Dalmanites sp. and Phacops salteri Kozlowski from the Alto el Cielo locality, in the Serranía de Perijá, north of Floresta. Eldredge \& Ormiston (1979, p. 148) listed Phacops (Viaphacops) sp., Dechenella boteroi, as well as undetermined odontopleurid and homalonotid. In his synthesis about the Devonian of Colombia, Barrett (1988, p. 710) only mentions the occurrence of "phacopid trilobites".

The aim of this contribution is not to provide a detailed morphological study of the trilobites from the Floresta Formation, but rather establish their age by comparing them with other well-documented trilobite faunas, and define possible palaeobiogeographic relationships between Colombia and other American domains during the Devonian. One of the main difficulties was the lack of recent studies on North American Devonian species. A brief description of the sixteen identified trilobite species (Figs 6-12) allows comparison with already well known

Figure 5. Schizobolus pilasiensis sp. nov. Upper part of the Floresta Formation, Las Pilas section, Givetian. • A, J, K, M - holotype, dorsal valve, MHNN.P.082780; latex cast of external mould in dorsal (A), posterodorsal (J), oblique (K) and lateral (M) views. $\bullet$ B - dorsal valve, latex cast of exterior, MHNN.P.082781. • C - dorsal valve, latex cast of exterior, MHNN.P.082782. • D, E, I - paratype, ventral valve, MHNN.P.082783, latex cast of exterior (D), external mould (E) and posteroventral view (I). $\bullet \mathrm{F}, \mathrm{L}-$ dorsal valve internal mould with external mould of opposite valve (F) and detail of dorsal visceral area (L), MHNN.P.082784. • G - ventral valve, internal mould, MHNN.P.082786. • H - ventral valve, internal mould, MHNN.P.082776. • N - dorsal valve, latex cast of exterior, MHNN.P.082778. Bar equals $1 \mathrm{~mm}$. 
Pierre Morzadec et al. • Trilobites and inarticulate brachiopods from the Devonian Floresta Formation of Colombia

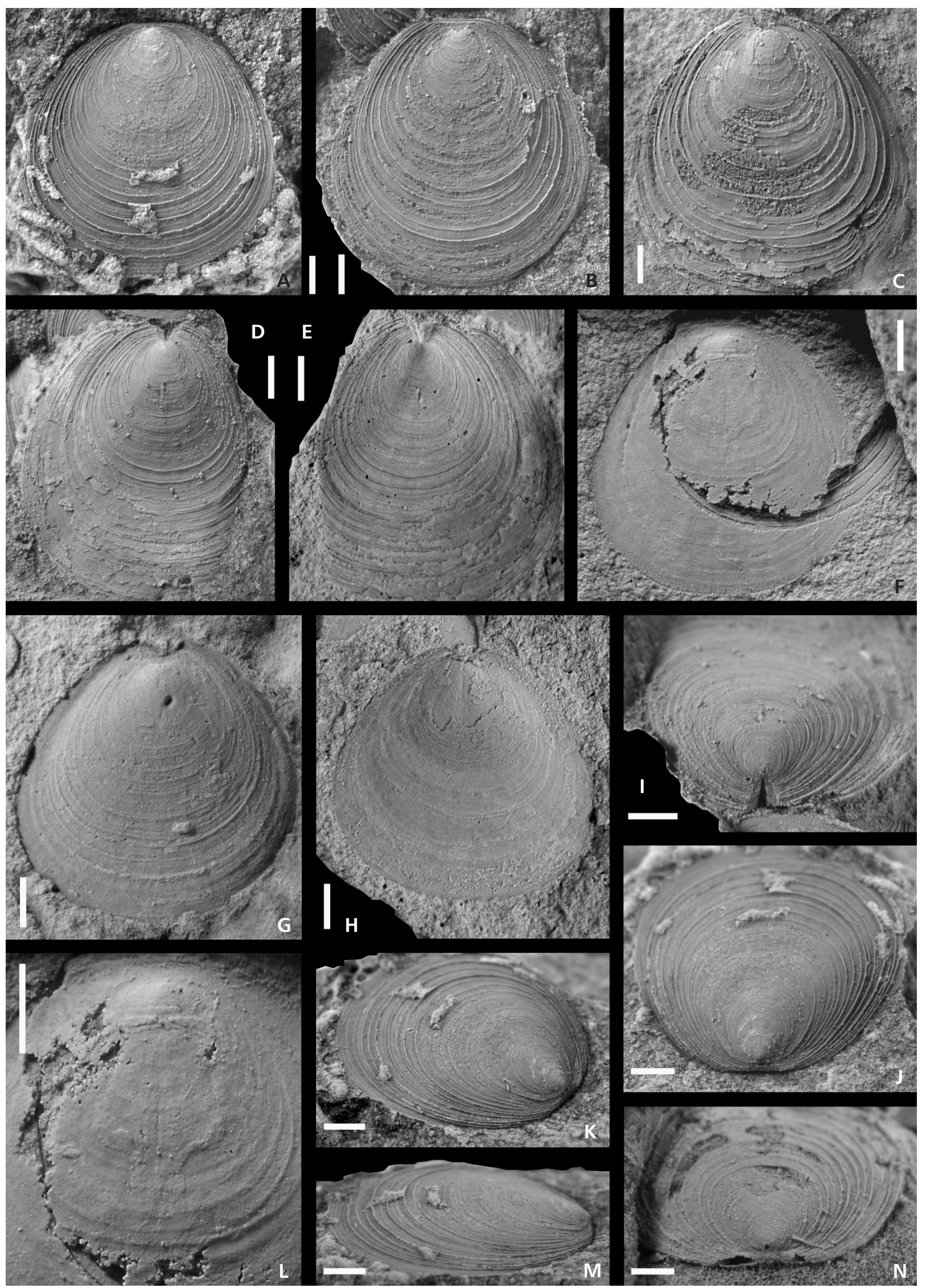


taxa, and provides further morphological data on some of them.

Family Homalonotidae Chapman, 1890

Subfamily Homalonotinae Chapman, 1890

\section{Genus Dipleura Green, 1832}

Type species. - Dipleura dekayi Green, 1832.

\section{Dipleura cf. dekayi Green, 1832}

Figure 6D, E

Material and locality. - Two small cranidia, (MHNN.P.082701, 082702), and an incomplete pygidium (MHNN.P.082703). First level of the upper half of the Floresta Formation, Quebrada Las Pilas section.

Description. - The two available cranidia are small-sized, $5 \mathrm{~mm}$ and $10 \mathrm{~mm}$ long respectively. The glabella is weakly convex, both longitudinally and transversally, and well defined anteriorly. The preglabellar border is flat and short. Axial furrows are subparallel, and weakly curved at the eyes, where the glabella narrows. These furrows exhibit two small anterolateral depressions. The occipital furrow is narrow, delimiting a flat occipital ring not higher than the high relief of the glabella. The anterior branches of the facial suture converge anteriorly. The palpebral lobes are located at mid-length of the glabella. On the smallest specimen, the glabella is shorter, markedly more convex, and the S1 furrows are weakly impressed. Similar ontogenetic morphological variations have already been described in Dipleura lanvoiensis Morzadec, 1969 from the Givetian of the Armorican massif, a species which is close to Dipleura dekayi Green, from the Hamilton Group of New York.

Discussion. - The paucity of the material collected does not allow identification at the species level. However the characters exhibited are very close to those of the North American species Dipleura dekayi which is common in the Givetian from Michigan (Stumm 1953) and Ontario where specimens are larger. Related species of Dipleura dekayi are known from the middle Devonian of Bolivia (Wolfart
1968), South Africa, Guinea Bissau, as well as in the Armorican Massif, W France (Morzadec 1983, p. 117).

Family Proetidae Hawle \& Corda, 1847

Subfamily Dechenellinae Přibyl, 1946

\section{Genus Dechenella Kayser, 1880}

Type species. - Phillipsia verneuili Barrande, 1852.

\section{Dechenella boteroi Caster \& Richter, 1950}

Figure 6A, B

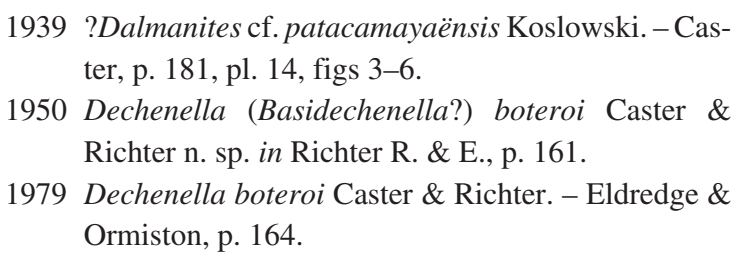

Material and locality. - One cephalo-thorax (MHNN.P.082704), one pygidium with thoracic segments (MHNN.P.82705), one internal mould of pygidium (MHNN.P.082706). Lower part of the Floresta Formation, Quebrada Monticelo section.

Description. - The single available cephalon is unfortunately strongly distorted. Cephalic border equals one-fifth as long as the cephalon. It exhibits a well developed rim and extends backwards with short and flat genal spines. Axial furrows are sub-parallel. Eye half as long as the glabella. Nine thoracic segments are preserved, they are flat with axial rings as wide as the pleurae. The pygidium is slightly wider than long; its axis includes 12 narrow rings, wider than the pleural lobes, and bearing a median tubercle. Pleural lobes with 9 pairs of narrow ribs separated by wide pleural furrows. Interpleural furrow narrow and shallow. The doublure of the pygidium is wide.

Discussion. - The pygidium outline and the number of pleural ribs are similar to the material described by R. Richter (1950, p. 162), as well as Dechenella boteroi figured by Caster (1939, pl. 14, figs 3-6); the species was described from the Floresta Formation of the Oriental Cordillera of

Figure 6. A-C, F, G-lower part of the Floresta Formation, Quebrada Monticelo section, late Emsian. D, E, H, F, K, I, L, M - upper part of the Floresta Formation, Las Pilas section, Givetian. - A, B - Dechenella boteroi Caster \& Richter. - A - cephalo-thorax, latex cast, dorsal view, $\times 10$, MHNN.P.082704. • B - thorax and pygidium, internal mould, dorsal view, $\times$ 4.5, MHNN.P.082705. • D, E - Dipleura cf. dekayi Green. Cranidium, latex cast. $\bullet$ D - dorsal view, E - anterior view, $\times$ 4, MHNN.P.082701. $\bullet \mathrm{F}, \mathrm{G}-$ Cordania gasepiu Clarke. Cephalon, dorsal view, F - internal mould, G - latex cast, $\times 2$, MHNN.P.082709. • H-M - Greenops cf. grabaui Lieberman \& Kloc. $\bullet$ H, I - cranidium, dorsal view, H - latex cast; I - internal mould, $\times 5$, MHNN.P.082740. • J - cranidium, latex cast, dorsal view, $\times 3$, MHNN.P.082736. $\bullet$ K - pygidium, latex cast, dorsal view, $\times 10$, MHNN.P.082743. $\bullet$ L - pygidium, internal mould, dorsal view, $\times 5$, MHNN.P.082741. $\bullet$ M - pygidium, latex cast, dorsal view, $\times 6$, MHNN.P.082744. $\bullet$ C - Mannopyge sp. Pygidium, internal mould, dorsal view, $\times$ 4, MHNN.P.082708. 
Pierre Morzadec et al. • Trilobites and inarticulate brachiopods from the Devonian Floresta Formation of Colombia
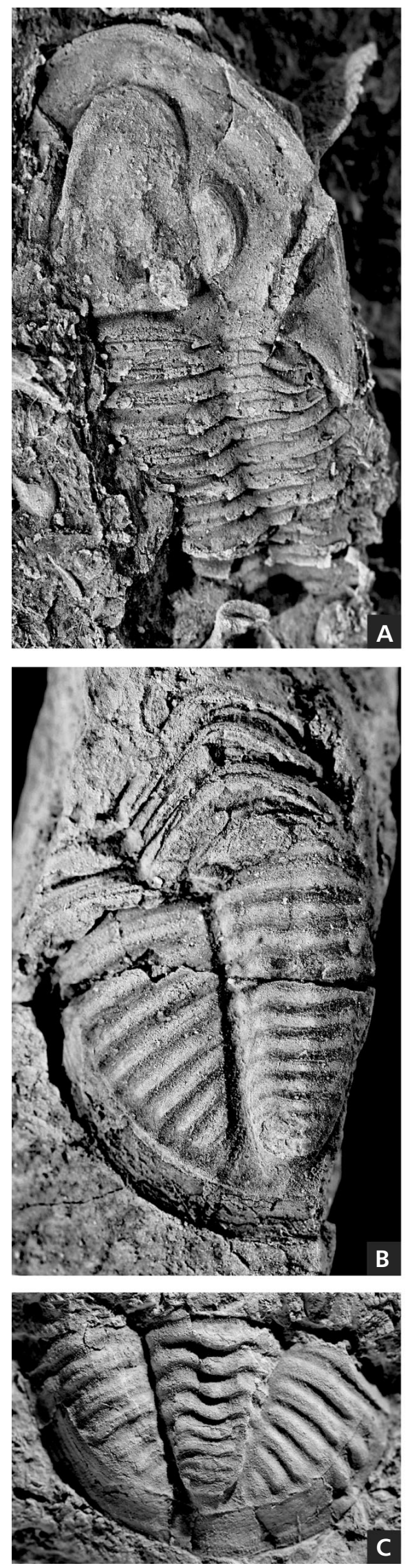
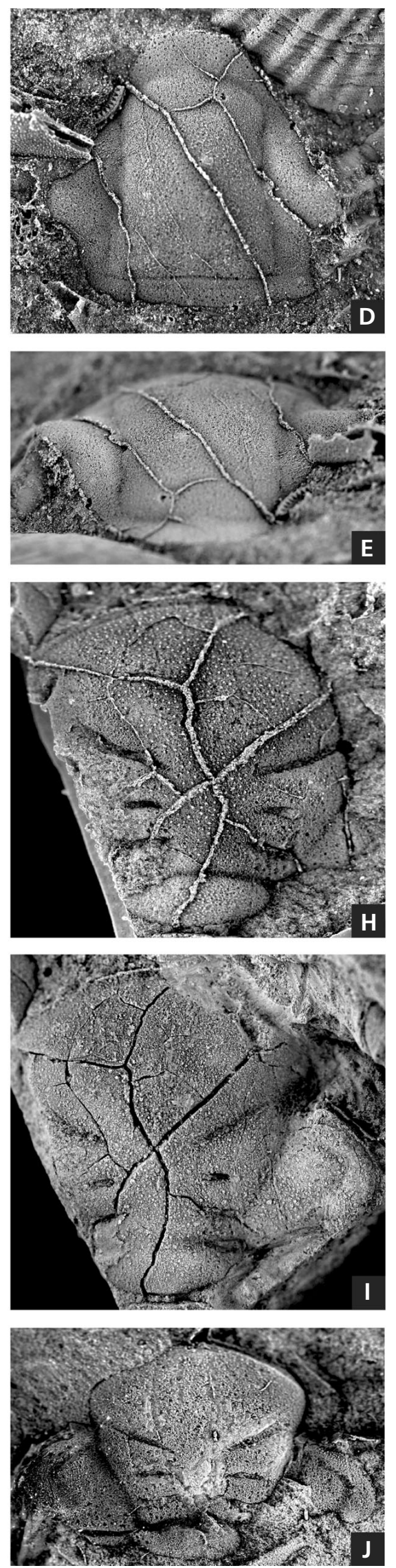
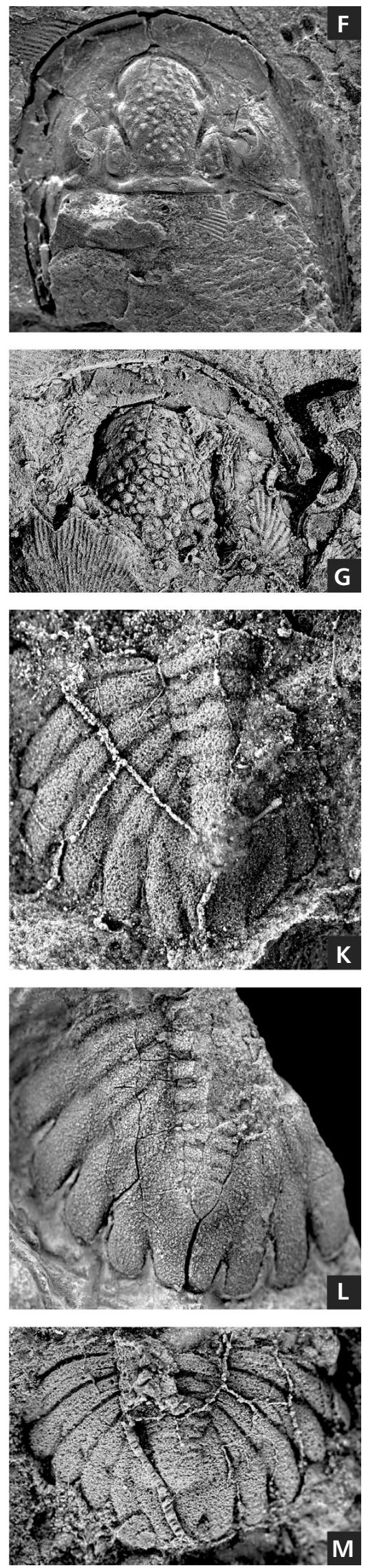
Colombia. The cephalon was hitherto unknown and, although distorted by tectonic, the new material adds to the knowledge of the species. The assignment of this species to the genus Dechenella, rather than to the genus Dalmanites, had already been suggested by Caster (1939, p. 181). The type-specimen (external mould of pygidium) of the species was reviewed and carefully described by Eldredge \& Ormiston (1979, p. 164).

Subfamily Warburgellinae Owens, 1973

\section{Genus Mannopyge Ludvigsen, 1987}

Type species. - Dechenella (Dechenella) halli Stumm, 1953.

\section{Mannopyge sp.}

Figure 6C

Material and locality. - One internal mould of a pygidium (MHNN.P.082708). Lower part of the Floresta Formation, Quebrada Monticelo section.

Description. - Pygidium semicircular in outline. Prominent longitudinal axis with 8 rings curved posteriorly, each possessing a median tubercle. Pleural lobes are convex and composed of 7 pleural ribs; their anterior part bears a tubercle in their distal part, whilst the posterior ones are short and do not reach the border of the pygidium. The doublure is wide.

Discussion. - The single internal mould of a pygidium possesses the diagnostic features of the genus Mannopyge. This genus is characterized by the development of tubercles on the distal end of the anterior half of the pleural ribs has to be noticed (see Ludvigsen 1987, p. 681, fig. 7). The genus is known from the upper part of the Lower Devonian of the New York state, and from the Amherstburg Formation of southern Ontario (Ludvigsen 1987).

Family Brachymetopidae Prantl \& Přibyl, 1951

\section{Genus Cordania Clarke, 1892}

Type species. - Phaethonides cyclurus Hall \& Clarke, 1888.

\section{Cordania gasepiou Clarke, 1907}

Figure 6F, G

1907 Cordania gasepiou nov.; Clarke, p. 172.

1960 Cordania gasepiu Clarke. - Whittington, p. 413, pl. 52, figs $1,2$.

1988 Cordania gasepiu Clarke. - Lespérance \& Sheehan, p. 1440.

Material and locality. - One cephalon, external and internal moulds (MHNN.P.082709). Lower part of the Floresta Formation, Quebrada Monticelo section.

Description. - Cephalon semi-circular in outline, and $12 \mathrm{~mm}$ long without genal spines. The cephalic border is $2.5 \mathrm{~mm}$ wide and strongly concave. It exposes a very thin concentric rim located at $0.5 \mathrm{~mm}$ from the glabellar frontal lobe. The prominent glabella is ornamented by stout tubercles, the size and the density of which increase posteriorly. The glabellar lobes L1 are twice as long as wide and bear small tubercles. The S1 are deep and well exposed anteriorly on the internal mould. The eyes are less prominent than the glabella and are located at the anterior part of the lateral glabellar lobes. Genal spines are long and wide. The doublure exhibits thin concentric rims.

Discussion. - The illustration published by Whittington (1960, pl. 52, figs 1, 2) allows comparison with the Clarke's type specimen from Québec. The shape of the cephalic border, and the ornament of strong glabellar tubercles are identical on the Colombian specimen and on the specimen from the Grande Grève Limestone of Québec. Lespérance \& Sheehan (1988, p. 1441) mentioned Cordania gasepiu from the Upper Gaspé Limestone of Québec.

Family Phacopidae Hawle \& Corda, 1847

Subfamily Phacopinae Hawle \& Corda, 1847

\section{Genus Viaphacops Maksimova, 1972}

Type species. - Phacops pipa Hall \& Clarke, 1888.

Viaphacops cristata (Hall, 1861)

Figure $7 \mathrm{~A}-\mathrm{H}$

?1965 Cryphaeus sp.; Morales, p. 109, pl. 8, fig. 6.

Figure 7. Lower part of the Floresta Formation, Quebrada Monticelo section, late Emsian. Viaphacops cristata (Hall). $\bullet$ A - cephalo-thorax, internal mould, dorsal view, $\times 2$, MHNN.P.082714. $\bullet$ B - cephalo-thorax, latex cast, dorsal view, $\times 2$, MHNN.P.082713. $\bullet$ C - cephalon, latex cast, dorsal view, $\times 6$, MHNN.P.082748. $\bullet$ D, E - cephalon, internal mould, dorsal $(\times 2)$ and lateral views $(\times 1.5)$, MHNN.P.082711. $\bullet$ F - complete exoskeleton, internal mould, lateral view, $\times 2$, MHNN.P.082710. $\bullet \mathrm{G}-$ cephalon, latex cast, antero-lateral view, $\times 2$, MHNN.P.082712. $\bullet$ H - pygidium, latex cast, dorsal view, $\times 6$, MHNN.P.082715. 
Pierre Morzadec et al. • Trilobites and inarticulate brachiopods from the Devonian Floresta Formation of Colombia
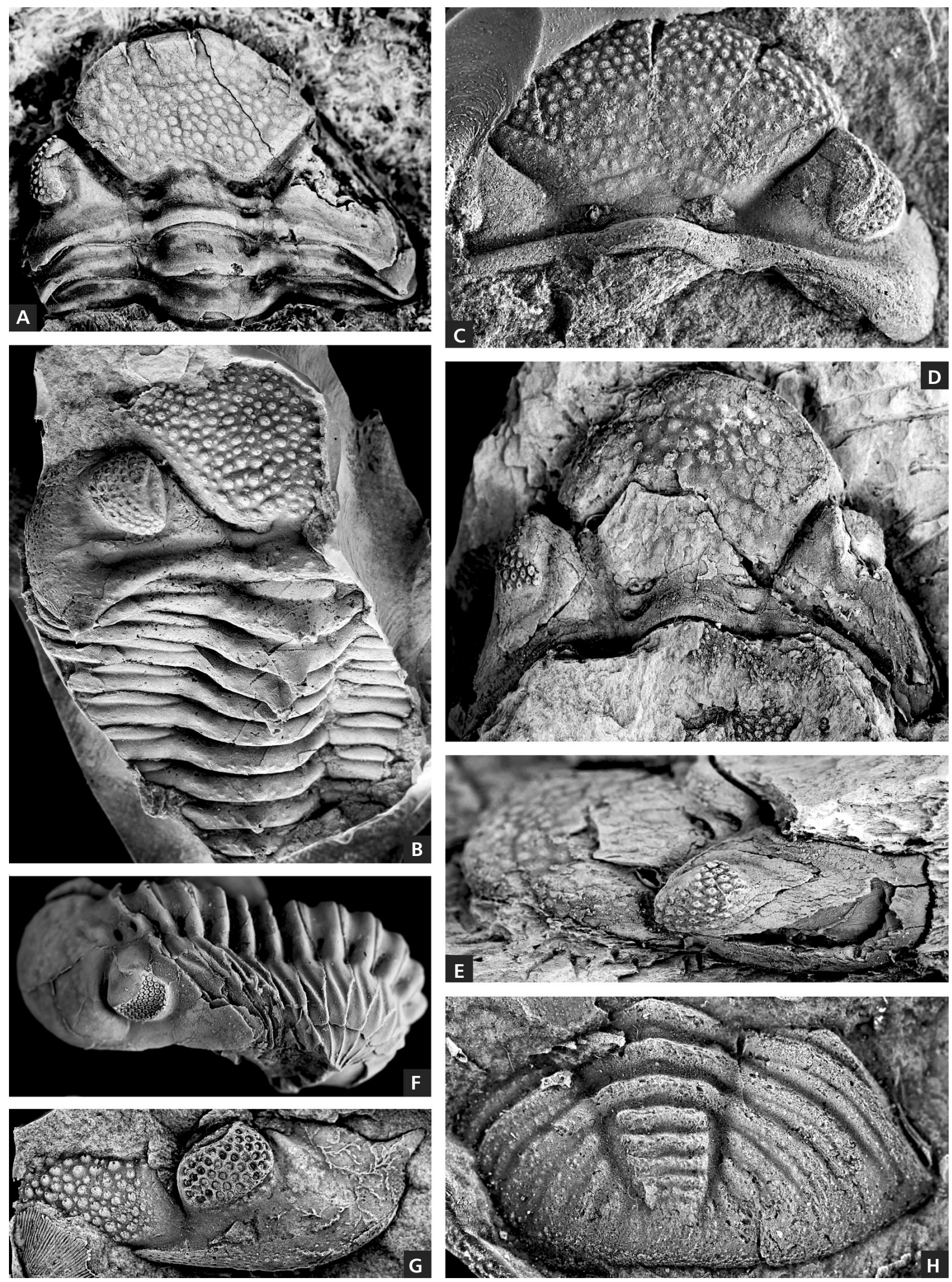
Synonymy. - Stumm (1954), Eldredge (1973), Campbell (1977), Lespérance (1991), and Ramsköld \& Werdelin (1991).

Material and locality. - One complete exoskeleton (MHNN.P.082710), one cephalon (MHNN.P.082711), one half of a cephalon (MHNN.P.082712), one cephalon and thorax (MHNN.P.082713), one cephalon and thorax, internal mould (MHNN.P.082714), one cephalon (MHNN.P.082748), one pygidium (MHNN.P.082715). Lower part of the Floresta Formation, Quebrada Monticelo section.

Description. - Large-sized cephalon with a moderately convex glabella bearing typical stout flattened tubercles. The variability in size and morphology of the glabellar tubercles is to observe. For example between the cephalons Fig. 7A-D with big flattened tubercles and Fig. 7B, C with smaller and sharp tubercles. The occipital ring is smooth, and the intermediate ring is restricted to two lateral tubercles. On three visual surfaces lenses number 14 dorsoventral files, with a maximum of 4 to 5 lenses per files. Each posterolateral angle bears a stout, dorsally curved, genal spine. No complete thorax is available. Each of the four anterior axial rings bears a median spine; rings 5 to 7 exhibit no more than a small tubercle, and rings 8 and 9 bear a spine. The pygidium axis is composed of nine rings, of which the two anterior ones bear a median tubercle. The seven pairs of pleural ribs do not reach the border. Interpleural furrows are developed on the four anterior ribs only. The anterior pleural bands are wider and more prominent than the posterior ones.

Discussion. - The stout tuberculate ornament of the glabella, combined with the development of genal spines and of spines on the thoracic axial rings are diagnostic of the species Viaphacops cristata, which includes several subspecies (see Eldredge 1973). According to this author, Viaphacops cristata cristata (Hall, 1861) is restricted to the Schoharie Formation of the New York state. Viaphacops cristata s.l. occurs in the Grande Grève Formation, Emsian of Québec, and in the Esopus and Schoharie formations, late Emsian, in the New York area, Ontario, Michigan, Indiana and Alabama (Eldredge 1973, p. 314).

\section{Viaphacops sp.}

Figure 8F, G

Material and locality. - One complete exoskeleton, MHNN.P.082716, one carapace, external mould,
MHNN.P.082707; three cephalons, MHNN.P.082717, 082718, 082719. Lower part of the Floresta Formation, Quebrada Monticelo section.

Description. - The glabella is flat, ornamented by stout tubercles. The anterior rim is bounded by a well marked furrow in front of the glabella. The visual surface possesses 13 to 14 dorsoventral files, with a maximum of 6 lenses by file. Genal angles are rounded, without apparent genal spines.

Discussion. - This form differs from V. cristata by the lack of genal spines, by a smaller visual area, and by the finer ornament of the glabella.

Family Dalmanitidae Vogdes, 1890

Sub-family Synphoriinae Delo, 1935

\section{Genus Anchiopsis Delo, 1935}

Type species. - Calymene anchiops Green, 1832.

\section{Anchiopsis armata (Hall, 1861)}

Figure 8A-D

1861 Dalmania anchiops var. armata; Hall, p. 56.

1940 Anchiopsis anchiops var. armatus (Hall, 1861). Delo, p. 84, pl. 10, figs 6, 7.

Material and locality. - Two incomplete cephalons, MHNN.P.082720, 082721, two internal moulds of pygidia, MHNN.P.082722, 082723. Lower part of the Floresta Formation, Quebrada Monticelo section.

Description. - The cephalon is large and ogival in outline, with genal angles elongated backward, but lacking genal spines. The occipital ring bears a stout spine, widened at the base. The anterior glabellar lobe flattens anteriorly. The central part of the glabella is depressed, unlike the L2 and L3 lobes. Axial furrows are shallow. The S1 furrows are short, and converge towards their adaxial extremities. The S2 are restricted to deep depressions connected to the axial furrows by very weak furrows. The L3 are more prominent than the L2, and the frontal lobes. Eyes are small, and situated with anterior edge opposite the S1 and posterior edge opposite the base of S3. The whole surface of the cephalon is smooth. The pygidium is triangular in outline. The rachis

Figure 8. Lower part of the Floresta Formation, Quebrada Monticelo section, late Emsian. • A-E - Anchiopsis armata (Hall). $\bullet$ A, B - cephalon, dorsal view; A - latex cast; B - internal mould, × 1.5, MHNN.P.082720. • D, E - cephalon, dorsal view; D - internal mould, $\times 1.5 ;$ E - latex cast, $\times 2$, MHNN.P.082721. $\bullet$ C - pygidium, internal mould, dorsal view, $\times 2$, MHNN.P.082723. $\bullet$ F, G - Viaphacops sp. Enrolled exoskeleton, antero-lateral view; F - internal mould; G - latex cast, $\times 3$, MHNN.P.082716. 
Pierre Morzadec et al. • Trilobites and inarticulate brachiopods from the Devonian Floresta Formation of Colombia
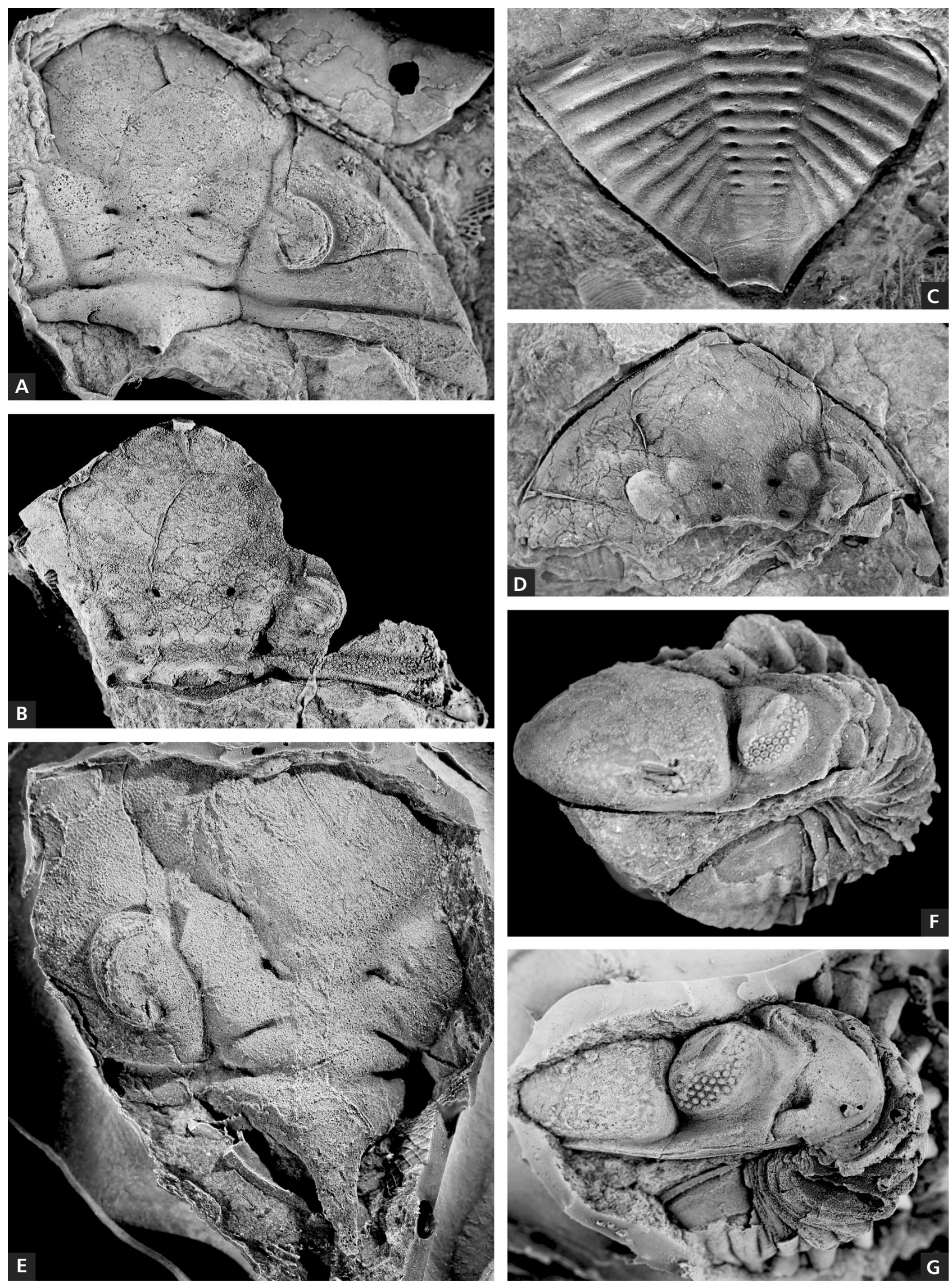
bears 13 rings, and is one-third as wide as the pygidium. The pleural lobes show 9 segments, and interpleural furrows are indistinct. The pygidium ends in a spine which is wide proximally.

Discussion. - Specimens from the Floresta Formation show a strong occipital spine, rounded genal angles, and a stout pygidial spine which allow their assignment to the species Anchiopsis armata (Hall). Lespérance \& Bourque (1971, p. 203) synonymized A. anchiops et A. armata despite the differences in the occipital and genal spines. A. armata is known from the late Emsian Schoharie grit, Schoharie area of New York. A. anchiops occurs in the same area, and in the Grande Grève Formation of Gaspé (Lespérance \& Bourque 1971, p. 204).

\section{Genus Synphoria Clarke, 1900}

Type species. - Dalmanites (Synphoria) stemmatus Clarke, 1900.

\section{Synphoria stemmata (Clarke, 1900)}

Figure 9A-C

1900 Dalmanites (Synphoria) stemmatus sp. nov., Clarke, p. 15, pl. 1, figs 6-16, pl. 2, figs 1, 2.

1940 Synphoria stemmatus Clarke, 1900. - Delo, p. 68, pl. 7, figs 1-3.

1971 Synphoria stemmata stemmata (Clarke, 1900). Lespérance \& Bourque, p. 194, pl. 26, fig. 4-7, $10-12$.

1994 Synphoria stemmatus Clarke. - Linsley, pl. 306, figs $1-13$.

Material and locality. - External and internal moulds of five pygidia (MHNN.P.082724-082728). Lower part of the Floresta Formation, Quebrada Monticelo section.

Description. - The pygidium is flattened, semicircular in outline, and lacking a posterior median spine and ornament. The axis is one-fourth as wide as the pygidium. Thirteen axial rings bear a median tubercle, they are separated in the median part of the axis by shallow furrows becoming deeper laterally. The eight pleural ribs are bounded by deep pleural furrows, as wide as the half-ribs. Interpleural furrows of the six anterior ribs are narrow, and well developed on the two thirds of the pygidial length. The anterior pleural bands do not reach the border of the pygidium, the posterior ones thicken and bend progressively backward before reaching the border. The rachis extends up to the pygidial border as a weak rim. The width of the pygidial doublure is one-fourth as wide as the pleural lobes.

Discussion. - The morphology of the Colombian pygidia compares closely with that of specimens illustrated by Clarke (1900, pl. 1), and reproduced by Linsley (1994, pl. 306, mainly fig. 9). The shape of the pleural ribs, as well as the rounded posterior border, agree with the intraspecific morphological variation of the species. Clarke (1901) described Synphoria stemmata from the Oriskany Formation of Becraft Mountain, New York. Lespérance \& Bourque (1971, p. 196) mentioned the species in the Oriskany Formation from Virginia, and the Bois Blanc Formation, late Emsian of Michigan.

\section{Genus Coronura Hall \& Clarke, 1888}

Type species. - Asaphus aspectans Conrad, 1841.

\section{Coronura cf. lessepsensis Lespérance, 1975}

Figure 9D, E

cf. 1975 Coronura lessepsensis n. sp., Lespérance, p. 122, pl. 4, fig. 6; pl. 5, fig. 1; pl. 7, fig. 1, text-fig. 6B.

Material and locality. - One complete exoskeleton, MHNN.P.082729. Lower part of the Floresta Formation, Quebrada Monticelo section.

Description. - The cephalon is semicircular in outline with long, flat genal spines, one-third as long as the cephalon. The cephalic border is wide and flat, undulating, with 4 nodes along its anterior margin. The glabella is limited by deep axial furrows. Furrows S1 are short and deep, S2 are restricted to a depression connected to the axial furrows by a weak furrow, whilst S3 are deep. The eyes are large, situated with anterior edge opposite $\mathrm{S} 1$ and posterior edge opposite S3. Visual surfaces are composed of very numerous small lenses. The occipital ring bears a median tubercle, and several large granules. The glabella and the genae are ornamented with numerous strong tubercles. The thoracic segments are also tuberculate. The axis of the pygidium

Figure 9. Lower part of the Floresta Formation, Quebrada Monticelo section, late Emsian. $\bullet$ A-C - Synphoria stemmata (Clarke); A - pygidium, internal mould, dorsal view, $\times 1.5$, MHNN.P.082724; B - pygidium, latex cast, dorsal view, $\times 4$, MHNN.P.082725; C - pygidium, internal mould, dorsal view, $\times$ 2, MHNN.P.082726. - D, E - Coronura cf. lessepsensis Lespérance. Incomplete specimen. - D - cephalon, internal mould, dorsal view; E - exoskeleton, latex cast, dorsal view, $\times 2$, MHNN.P.082729. $• F, G-$ Colombianaspis gen. nov. carvalhoae sp. nov. Cephalon, latex cast; F - dorsal view, $\mathrm{G}-$ lateral view, $\times 7$, MHNN.P.082752. 

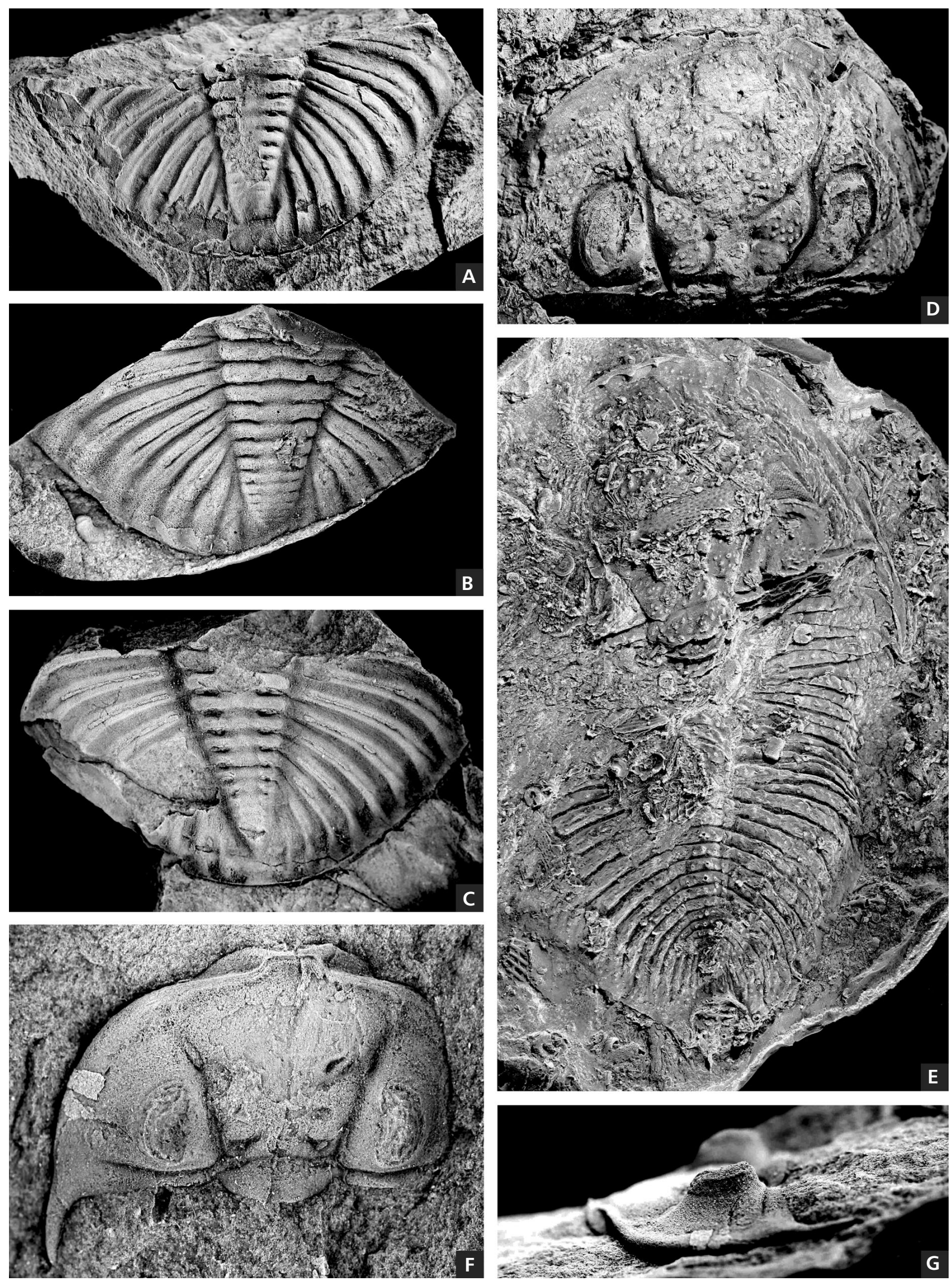
includes 16 rings, each bearing a stout median tubercle and two pairs of lateral tubercles. Sixteen pairs of narrow pleural ribs, with numerous small tubercles, are separated by deep pleural furrows. Interpleural furrows are not visible on the specimen. The axis ends in a median posterior rim. The pygidial border exhibits a median posterior indentation.

Discussion. - The morphological characters of the pygidium of the single available specimen, among which the indentated posterior border, and its dense tuberculate ornamentation, strongly suggest that the Colombian specimen belongs to the genus Coronura (Stumm 1954, Holloway \& Carvalho 2010, p. 73). This form is close to the species lessepsensis Lespérance based on the lack of pygidial spines and the number of pleural ribs. The genus Coronura occurs during the Emsian and the Eifelian of North America. According to Lespérance (1975, p. 122), Coronura lessepsensis is known only by its pygidium from the Grande Grève Formation (Etymothyris Zone) in Emsian of Gaspé.

Synphoriinae indet.

Figure 11D-G

Material and locality. - One incomplete cranidium, MHNN.P.082730; three incomplete pygidia, MHNN.P.082731-082733; one internal mould of a pygidium, MHNN.P.082734. Lower part of the Floresta Formation, Rio Pargua section (Fig. 3).

Description. - The incomplete cranidium does not allow a complete description, however, the glabella appears relatively flattened with a large anterior lobe ornamented with large tubercles. The S2 furrows are limited to two deep adaxial depressions and the S3 are well developed. The $\mathrm{L} 1$ are reduced. The pygidia are large and relatively flattened. The axis, one-fourth of the pygidium width, is limited by weakly divergent dorsal furrows. It is composed of 18 rings. The pleural lobes are composed of 12 pairs of pleural ribs, each bearing 3 tubercles. These tubercles are stouter on the third pair where the lateral ones develop as a stout spine. Along the axis, the second, third, seventh, eighth, twelve, thirteenth and seventeenth rings bear a median spine, whilst others are smooth. The interpleural furrows of the first three pairs of pleural ribs are weakly developed. The posterior end of the pygidium is not preserved.
Discussion. - The glabellar and pygidial segmentation suggest that this form belongs to the Subfamily Synphoriinae. The morphological characters of the pygidia are in agreement with those described by Hall \& Clarke (1888, p. 31) for Dalmanites phacoptyx Hall \& Clarke, 1888: the same number of pygidial pleural ribs, axial rings with or without median spine in alternance, presence of irregularly distributed spines or stout tubercles on the anterior pleural band. They also possess like Dalmanites perceensis Clarke, 1905, an ornament of alternating median spines and tubercles on the pleural lobes as well as on the axis. Since generic assignment of the species phacoptyx and perceensis has not yet been established, the original generic assignments are provisionally used. Dalmanites phacoptyx is known from the Upper Helderberg Limestones of Ontario. Delo (1940, p. 60) mentioned the species from the Lower Onondagan (Decewville) in Ontario and from the Oriskany Formation of the Becraft Mountain of New York. Dalmanites perceensis is known from the Murailles Limestones of the Percé area in Québec.

Family Acastidae Delo, 1935

Sub-family Asteropyginae Delo, 1935

\section{Genus Greenops Delo, 1935}

Type species. - Cryphaeus boothi Green, 1837.

\section{Greenops cf. grabaui Lieberman \& Kloc, 1997} Figure 6H-M

cf. 1997 Greenops grabaui n. sp., Lieberman \& Kloc, p. 93.

Material and locality. - Two internal moulds of a cranidium, MHNN.P.082735, MHNN.P.O82739; three external moulds of cranidia, MHNN.P.082736-082738; one cranidium, external and internal moulds, MHNN.P.082740; two pygidia, internal moulds, MHNN.P.082741-082742; five external moulds, MHNN.P.082743-082747; one incomplete librigena, MHNN.P.082749. Upper part of the Floresta Formation, Quebrada Las Pilas section.

Description. - The collected material is small-sized; cranidium 5.5 to $10 \mathrm{~mm}$ long and pygidium 5 to $7 \mathrm{~mm}$. The glabella is as wide as long, and weakly arched, but relatively more convex in small specimens. The glabellar furrows

Figure 10. Lower part of the Floresta Formation, Quebrada Monticelo section, late Emsian. • A-G - Colombianaspis gen. nov. carvalhoae sp. nov. - A, B - cephalo-thorax, MHNN.P.082759; A - internal mould; B - latex cast, $\times 6 . \bullet$ C, D - holotype, MHNN.P.082750. Complete exoskeleton, internal mould; $\mathrm{C}-$ thorax and pygidium, dorsal view, $\times 5$; D - cephalon, anterior view, $\times 8 . \bullet$ E - cephalon, MHNN.P.082758; internal mould, dorsal view, $\times 7$. $\bullet$ F, G - cephalon, MHNN.P.082761, latex cast: F - dorsal view; $\mathrm{G}$ - lateral view, $\times 5$. 
Pierre Morzadec et al. - Trilobites and inarticulate brachiopods from the Devonian Floresta Formation of Colombia
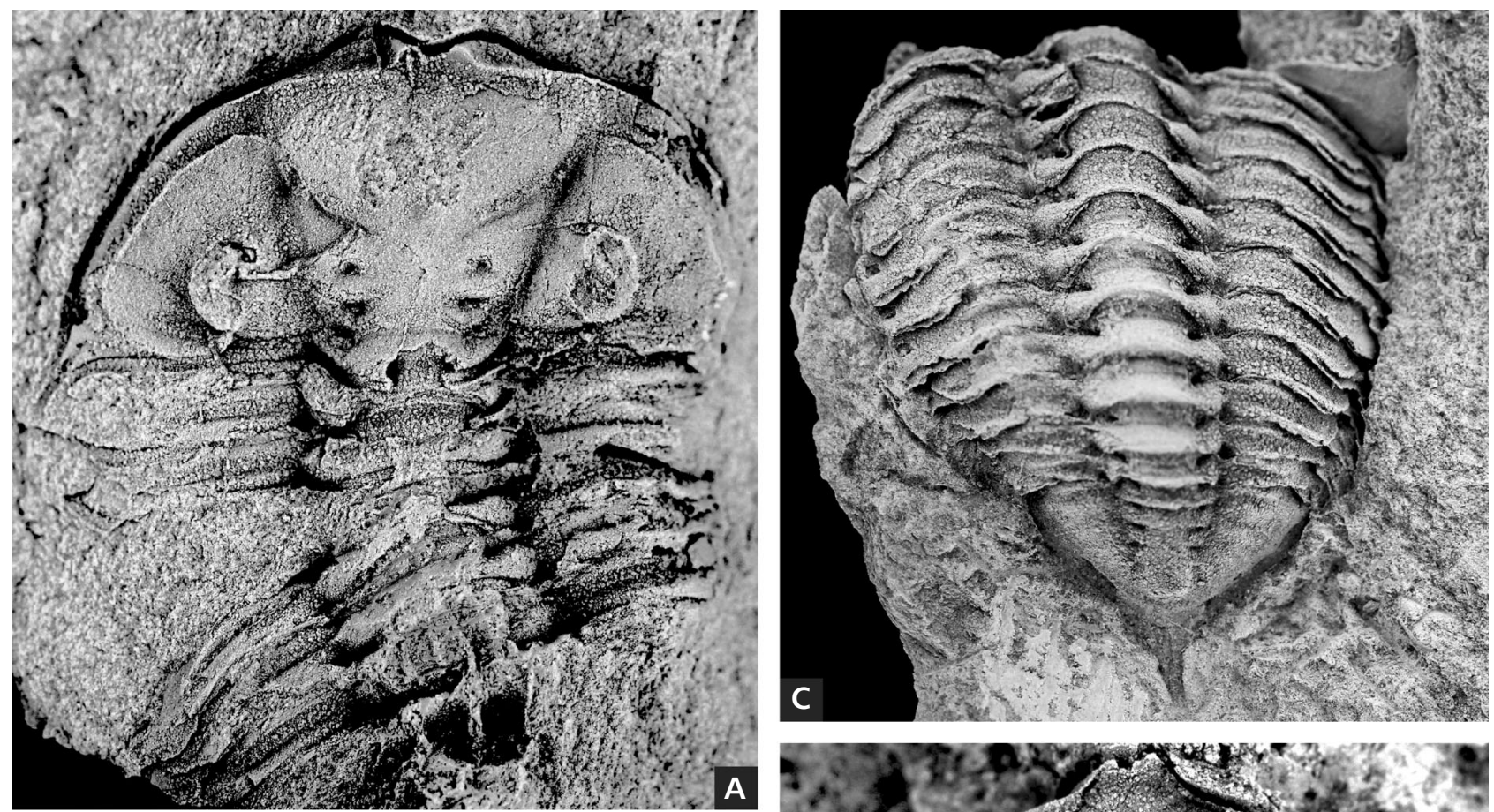

A
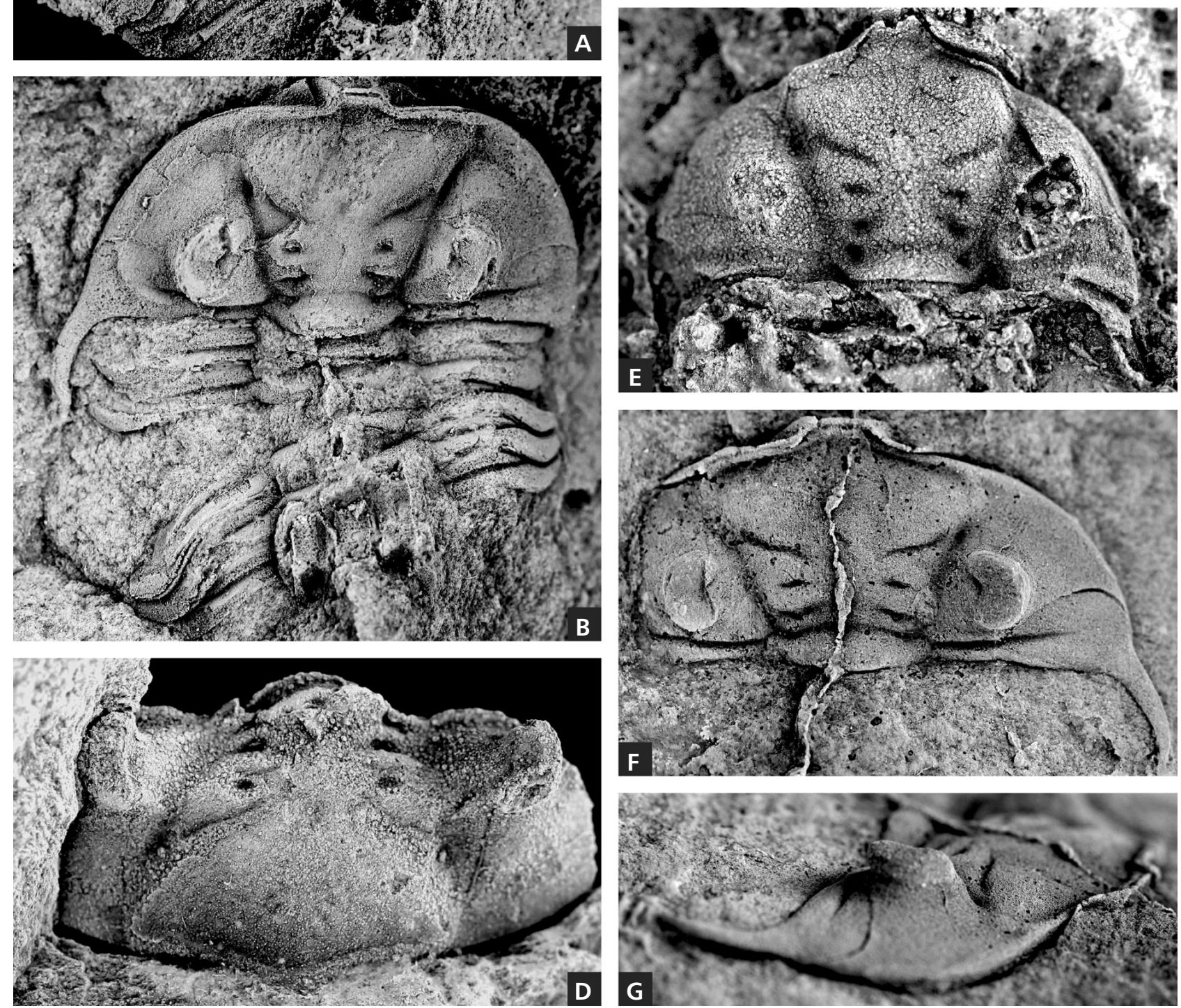
S2 appear as deep depressions separated from the axial furrows. The eyes are relatively long, extending from $\mathrm{S} 1$ to the extremity of S3, and they dorsally extend beyond the glabella. The anterior branchs of the facial suture are weakly separated from the glabellar frontal lobe. The occipital ring is elevated above the glabella and bears a small median tubercle. The glabellar surface is granulose. Any fragments of the thorax are preserved. The pygidium is composed of 11 axial rings lacking median tubercle. The five pairs of pleural ribs have narrow but deep interpleural furrows. The posterior pleural bands are short and the anterior ones extend as lateral spines. Anterior and posterior pleural bands share the same relief. The five pairs of marginal spines are short, wide, rounded at their distal end, with narrow interspaces. The posteromedian spine is wide, rectangular in outline and shorter than the fifth spines.

Discussion. - The morphology of the cephalon, the segmentation of the glabella and the pygidium, and the presence of 11 axial rings on the pygidium, suggest that the specimens can be assigned to the genus Greenops Delo. The genus is well documented from the Givetian of North America. The small size of the material and its preservation make any specific identification uncertain. Nevertheless, according to Lieberman \& Kloc (1997), the Colombian material can be tentatively assigned to Greenops grabaui Lieberman \& Kloc from the Appalachian Givetian Hamilton Group.

\section{Family Calmoniidae Delo, 1935}

\section{Genus Colombianaspis gen. nov.}

Type species. - Colombianaspis carvalhoae gen. et sp. nov.

Etymology. - From Colombia, the country where the material was collected, and aspis: spine.

Diagnosis. - Small trilobite with the anterior part of the cephalon bearing a short angular extension bounded laterally by two small flat areas, eyes long and located posteriorly, visual surfaces narrow with a maximum of 4 lenses in each dorso-ventral file; genal spines short and weakly curved; occipital ring smooth; glabellar segmentation of calmoniid type; L1 narrow; L2 and L3 fused in their abaxial part; pygidium small, convex, with 5 axial rings and 5 pairs of pleural ribs, ending in a long median spine; no lateral spines.

Discussion. - The glabellar segmentation of the new genus is diagnostic for the family Calmoniidae. Although it shares affinities with some species of the genus Metacryphaeus, it strongly differs in its pygidium. The pygidium, characterized by few rings, a smooth border, and a well developed terminal spine, show some similarity with the genus Bainella Rennie (Cooper 1982). The new genus Colombianaspis is hitherto monospecific. It show some convergences with the cephalon mentioned and figured as Centauropyge sp. (see discussion below) in the Indian Coves Formation of the Upper Gaspé Limestone, Emsian of Gaspé, by Lespérance \& Sheehan (1988).

\section{Colombianaspis carvalhoae sp. nov.} Figures 9F, G, 10A-G

aff. 1988 Centauropyge n. sp. - Lespérance \& Sheehan, pl. 3, fig. 1.

Holotype. - Complete exoskeleton MHNN.P.O8275O, figured Fig. 10C-D.

Etymology. - In acknowledgement of Maria da Gloria Pires de Carvalho for her help.

Type horizon. - Lower part of the Floresta Formation, late Emsian.

Type locality. - Quebrada Monticelo section, Colombia.

Material and locality. - Three complete exoskeletons, internal moulds, MHNN.P.082750-082751, MHNN.P.082757; 1 cephalon, internal mould, MHNN.P.082752; 1 cranidium, MHNN.P.082753; 3 cephalons, MHNN.P.082754-082756; one cephalon, MHNN.P.082758; two cephalo-thorax, MHNN.P.082759-082760; one cephalon, MHNN.P.082761. Lower part of the Floresta Formation, Quebrada Monticelo section.

Diagnosis. - As for the genus.

Description. - The cephalon is twice as wide as long and

Figure 11. Lower part of the Floresta Formation, late Emsian. A-C - Quebrada Monticelo section; D-G - Rio Pargua section. • A, B - cf. Tarijactinoides sp. nov. Complete exoskeleton, latex cast, MHNN.P.082762: A - dorsal view; B - antero-lateral view of the cephalon, $\times 4$. $\bullet$ C - Calmoniidae indet. Cranidium, internal mould, dorsal view, $\times 2.5$, MHNN.P.082763. $\bullet$ D-G - Synphoriinae indet. $\bullet$ D - pygidium, latex cast, dorsal view, $\times 1.5$, MHNN.P.082731. - E - pygidium, internal mould, dorsal view, $\times 1$, MHNN.P.082732. $-\mathrm{F}-$ pygidium, internal mould, dorsal view, $\times 1$, MHNN.P.082733. $\bullet \mathrm{G}$ - cranidium, internal mould, dorsal view, $\times$ 1, MHNN.P.082730. 

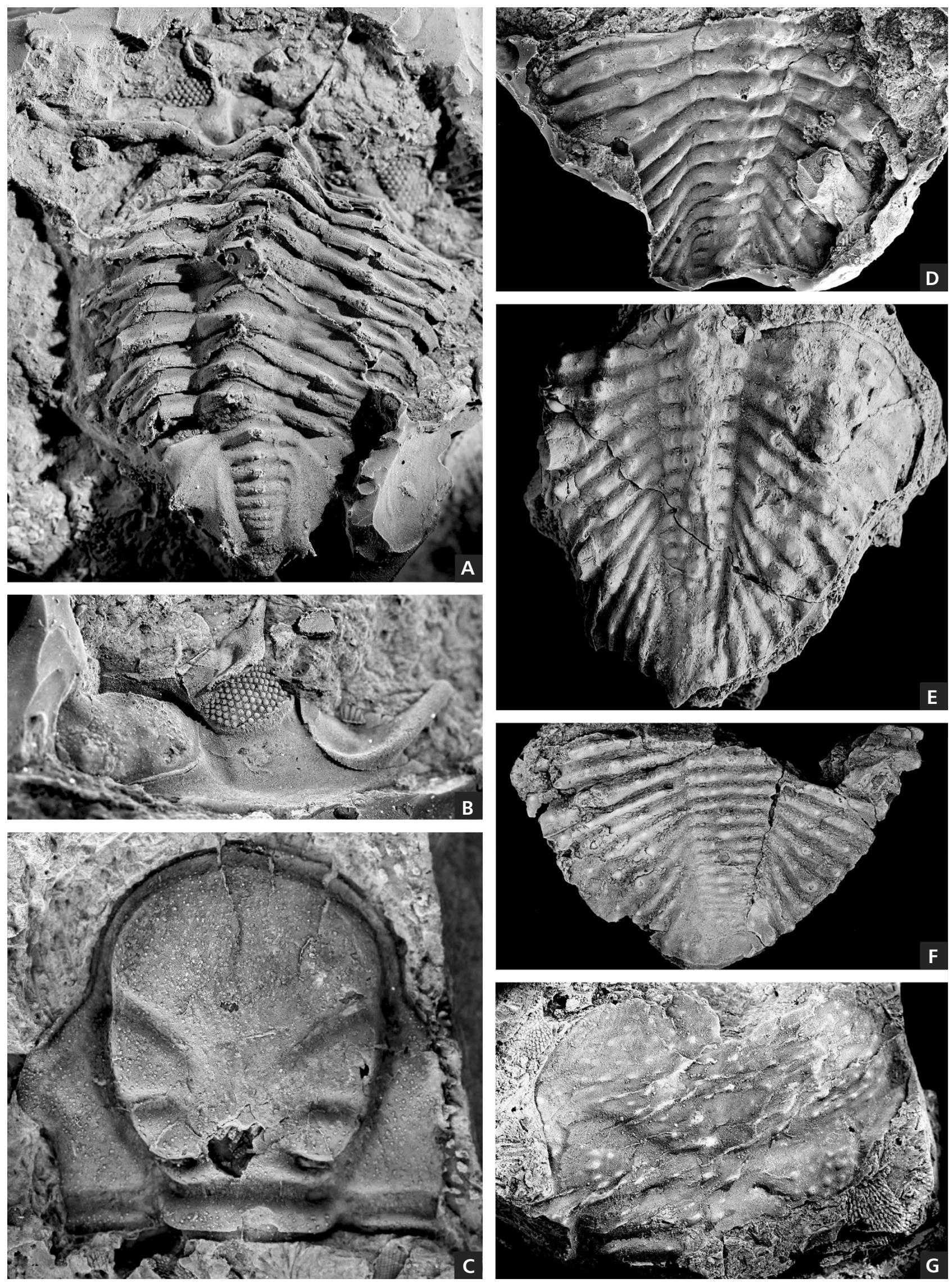
is 5.5 to $7.5 \mathrm{~mm}$ long. Its anterior margin extends in a short angular extension. On each side of the extension, the cephalic border exhibits a typical small area, flat and subvertical (see Fig. 9F, G). The anterior branchs of the proparian suture show an angular line, following the outline of the extension. The frontal lobe of the glabella is flat and smooth. The furrows S2 appear as deep depressions separated from the doral furrows. The lobes L2 and L3 are prominent, but L3 is more prominent than L2. Eyes one-third as long as the cephalon, elevated above the glabella and located posteriorly. The visual surfaces are small, with 17 dorso-ventral files, each with a maximum of 4 lenses. The occipital ring is smooth. Genal spines one-third as long as the cephalon; they are curved inwards and subcircular in cross section. The thorax is composed of 11 segments; axial rings one-third as wide as the thorax. The pygidium is small, almost rounded in outline, and markedly convex transversally; it exhibits 5 axial rings, and 5 pairs of pleural ribs. The border is narrow and extends posteriorly in a flat, long median spine, long about half of the length of the axis (see Fig. 10C). No marginal spines.

Discussion. - The cephalon from the Floresta Formation have some similarity with the Acastavinae figured by Lespérance \& Sheehan (1988, pl. 3, fig. 1) from Gaspé, and assigned by the authors to the genus Centauropyge Haas, 1968 from the late Emsian of Turkey. Nevertheless the Canadian cephalon, single specimen, an internal mould, differs markedly by the contour, the glabellar furrows and the genal spines from the cephalon of the Turkish Centauropyge. However, the segmentation of the cephalon of the Colombian material and also the morphology of the pygidium with its posterior median spine, are distinct in the Turkish, Canadian and Colombian forms. Lespérance \& Sheehan reported Centauropyge n. sp. from the Upper Gaspé Limestone, Indian Cove Formation (Emsian) of Gaspé.

\section{Genus Tarijactinoides Suarez Soruco, 1971}

Type species. - Tarijactinoides jarcasensis Suarez Soruco, 1971.

1980 Tarijactinoides Suarez Soruco, 1971. - Eldredge \& Branisa, p. 277.

\section{cf. Tarijactinoides sp. nov.} Figure 11A, B

Material and locality. - One incomplete exoskeleton, internal and external moulds, MHNN.P.082762. Lower part of the Floresta Formation, Quebrada Monticelo section.

Description. - The incomplete cephalon shows a markedly convex glabellar frontal lobe with a median spine. The glabellar segmentation is not preserved. The eyes are large, with at least 25 dorso-ventral files, each bearing a maximum of 8 lenses. The posterior margin of the palpebral lobes shows a relatively long and erected spine. The occipital ring bears a median spine. The anterior branch of the cephalic suture is accentuated by a thin rim. The posterior border of the cephalon bears a stout metafixigenal spine. The base of a genal spine is preserved. The thorax is composed of 11 segments, curved posteriorly, each axial ring bearing a thin median spine. The pleurae are ornamented with a mediolateral spine inserted on the posterior margin of each pleural rib which laterally ends in a flat, relatively short, and posteriorly bent pleural spine. The pygidium is small and triangular in outline; its axis is composed of 8 rings with a median tubercle. Pleural lobes are relatively flat; two weakly distinct pleural ribs bear an erected spine inserted where the ribs bend ventrally. The second pleural ribs are parallel to the axis. The third pair of pleural ribs is almost undistinguishable, and there are no furrows on the pleural lobes. The border of the pygidium is complete, and ends in a short, triangular median spine.

Discussion. - The Colombian specimen referred herein to cf. Tarijactinoides sp. nov. shares some characters (Eldredge \& Branisa 1980, p. 277) with the Bolivian genus Tarijactinoides Suarez Soruco, 1971. Like Tarijactinoides it exhibits a spine on the frontal glabellar lobe, a metafixigenal spine, spinose thoracic segments, and a small pygidium. The main differences lie in the size of the eye and in the number of pygidial ribs. The unique incomplete specimen does not allow the erection of a new genus, nor a new species. However cf. Tarijactinoides sp. nov. differs from the two hitherto known species, namely $T$. jarcasensis Suarez Soruco and T. tikanensis Eldredge \& Branisa, from the late Lochkovian-early Pragian Scaphocoelia Zone of Bolivia, by a lower number of pleural ribs on the pygidium (3 pairs instead of 7) among others (Vaccari et al. 1994).

Figure 12. Lower part of the Floresta Formation, late Emsian. A, B, D - Quebrada Monticelo section; C - section W-SW of Otenga; E-G - Morro Cabezon E-NE of Cerinza. - A-D - Belenopyge contusa (Hall \& Clarke). • A - cranidium, latex cast, dorsal view, $\times 4$, MHNN.P.082765. - B, D - cranidium, dorsal view; B - internal mould; D - latex cast, $\times 3$, MHNN.P.082766. $\bullet$ C - pygidium, internal mould, dorsal view, $\times 3.5$, MHNN.P.082767. • E-G - Kettneraspis callicera (Hall \& Clarke). • E, F - cephalo-thorax, dorsal view; E - latex cast; F - internal mould, $\times 3$, MHNN.P.082769. • G - distorted thorax and pygidium, latex cast, dorsal view, $\times$ 4, MHNN.P.082770. 

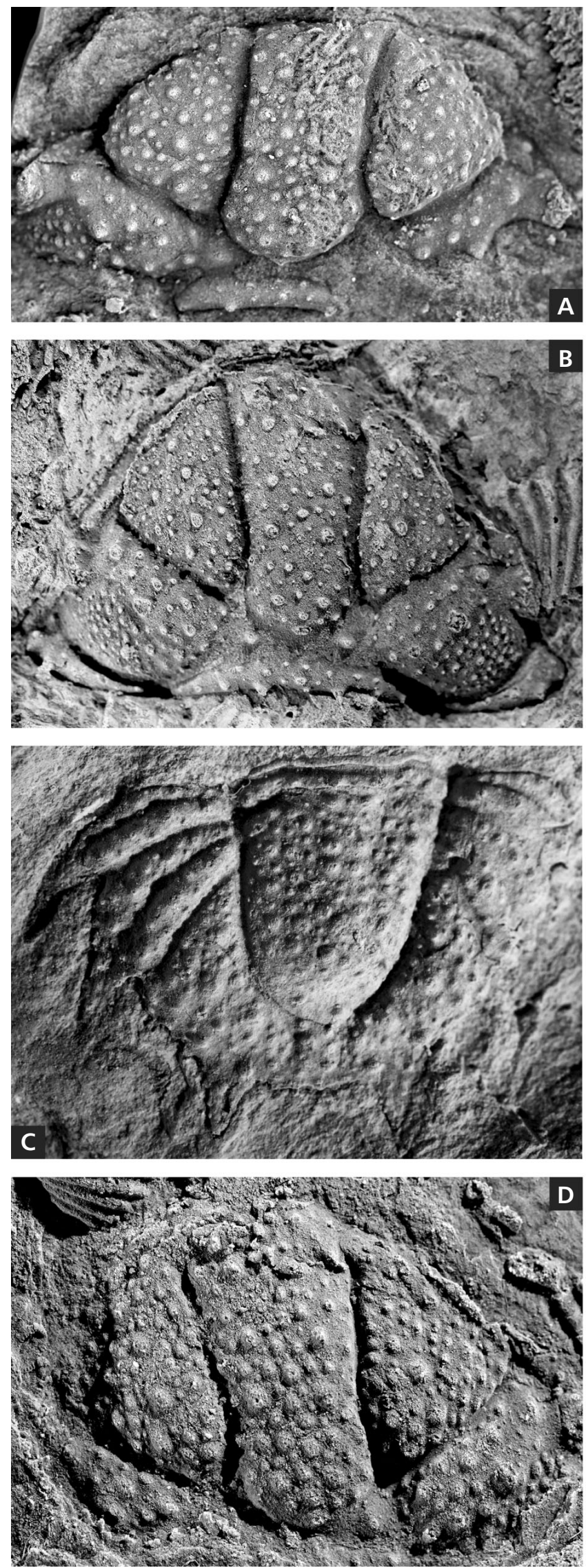
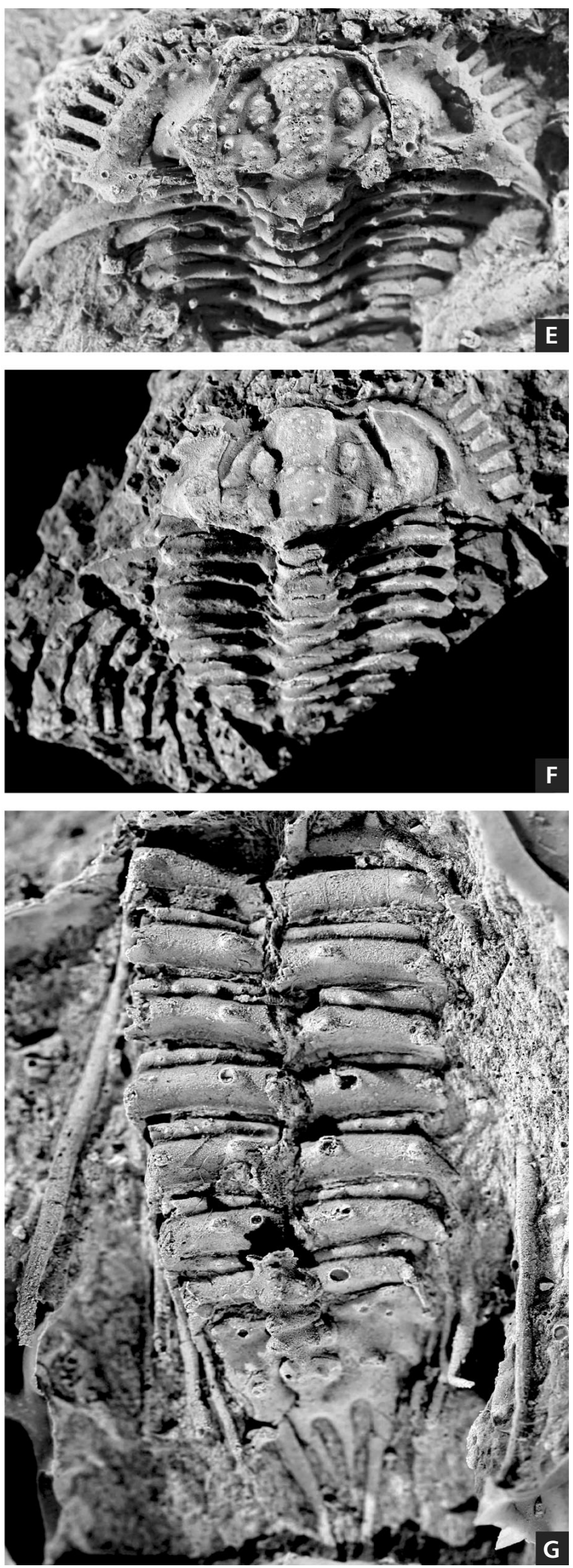
Calmoniidae indet.

Figure 11C

Material and locality. - Two cranidia, internal moulds, MHNN.P.082763-082764. Lower part of the Floresta Formation, Quebrada Monticelo section.

Description. - The frontal lobe of the glabella is narrower than L3, conferring the glabella a "barrel-like" outline. L1 very narrow, $\mathrm{S} 1$ curved, $\mathrm{S} 2$ connected with the axial furrows and deeper in their proximal part; S3 markedly oblique. The anterior branchs of the suture separated from the anterior lobe. The preglabellar furrow is well developed. Eyes with anterior edge opposite middle of L2 and posterior edge opposite middle of L3.

Discussion. - The glabellar shape and segmentation, the location and relative size of the palpebral lobes, only allow to place these specimens within the family Calmoniidae.

Family Lichidae Hawle \& Corda, 1847

Subfamily Trochurinae Phleger, 1936

\section{Genus Belenopyge Peck \& Vaneck, 1991}

Type species. - Lichas balliviani Kozlowski, 1923.

\section{Belenopyge contusa (Hall \& Clarke, 1888) Figure 12A-D}

Synonymy. - See Ludvigsen (1987, p. 687, figs 11, 12a-h).

Material and localities. - One cranidium, MHNN.P.082765; two cranidia, MHNN.P.082766, 082768, thorax and pygidium, MHNN.P.O82785, lower part of the Floresta Formation, Quebrada Monticelo section. one pygidium, internal mould, MHN.P. 082767, lower part of the Floresta Formation, W-SW of Otenga.

Description. - The cephalon is twice as wide as long and surrounded by a narrow cephalic border. The central part of the glabella is subrectangular in outline, bounded by weakly divergent furrows and characterized by numerous spinose tubercles. The lateral glabellar lobes are triangular, and bounded by deep furrows. The occipital ring bears numerous tubercles among which three are better developed. The eyes are small, and widely separated from the glabella. The thorax is relatively flat. The thoracic pleurae bear 5 tubercles. The pygidial axis is prominent, laterally bounded by deep furrows, and wider than the pleural lobes. A unique axial ring is visible on the axis that ends in a median posterior rib. Each pleural lobe possesses three ribs. The pygidial border is characterized by three pairs of short, flat- tened, and posteriorly bent marginal spines. The whole pygidium bears numerous spinose tubercles.

Discussion. - The generic name Belenopyge Peck \& Vaneck, 1991 is considered as synonym of Lobopyge Přibyl \& Erben, 1952 by Ebach \& Ahyong 2001. Özdikmen (2009) considers Lobopyge as invalid and substitute the name $B e$ lenopyge for Lobopyge. The genus Belenopyge has a wide geographic distribution. It is represented by numerous species in the Emsian and the Eifelian of Europe (Czech Republic, Germany, France), as well as from Morocco and Australia (Ebach \& Ahyong 2001). It has also been described from North America, the New York area and Ontario, and from South America where the subfamily is represented by Belenopyge balliviani (Kozlowski, 1923). The Colombian specimens share all the characters of Belenopyge contusa: shape of the glabella, anteriorly reduced cephalic border, shape and length of pygidial spines, granulose ornament of both the glabella and pygidium. Belenopyge contusa is known to occur in the Onondaga Limestones of the New York area, and in the Formosa member of the Amherstburg Formation (late Emsian, serotinus Zone) of SW Ontario (Ludvigsen 1987).

Family Odontopleuridae Burmeister, 1843

Sub-family Odontopleurinae Burmeister, 1843

\section{Genus Kettneraspis Prantl \& Přibyl, 1949}

Type species. - Acidaspis pigra Barrande, 1872.

Kettneraspis callicera (Hall \& Clarke, 1888) Figure 12E-G

1888 Acidaspis callicera n. sp.; Hall \& Clarke, p. 69, pl. XVIb, figs 1-13.

?1965 Odontopleura callicera (Hall \& Clarke). - Morales, p. 89 , pl. VIII, figs 3,4 .

2002 Kettneraspis callicera (Hall \& Clarke). - Whiteley, Kloc \& Brett, pl. 34.

Material and locality. - One complete exoskeleton, MHNN.P.082770; one cephalo-thorax, MHNN.P.082769; one thorax and pygidium, MHNN.P.082771; one cranidium internal and external moulds, MHNN.P.082772. Lower part of the Floresta Formation, Morro Cabezon, E-NE of Cerinza.

Description. - The cephalon is $7 \mathrm{~mm}$ long. The librigenae bear 12 spines along their lateral margin, the length of which increases backward, and 6 erected spinose tubercles. The anterior margin of the cranidium bears 10 short spines. The occipital ring possesses 3 pairs of tubercles, and a short 
median spine. The central part of the glabella widens anteriorly, and is ornamented by very stout tubercles. The lateral ridges bear 4 tubercles. Lateral lobes, as well as the eyes, show some stout tubercles. The thoracic axis, very large, exhibits 4 spinose tubercles on each ring. Each of the pleurae of the 9 thoracic segments is ornamented by 2 spinose tubercles, and extends as flattened and curved pleural spines, the length of which decreases posteriorly. The length of the pleural spines of the 4th thoracic segment reaches the extremity of the pygidium. The pygidium possesses two tubercular axial rings, and two pleural ribs. The anterior pleural rib bears 2 tubercles, whereas the posterior one has one tubercle only. The pygidial margin bears four pairs of marginal spines; the third marginal spines are twice as long as the fourth ones.

Discussion. - The Colombian specimens are assigned to the genus Kettneraspis Prantl \& Přibyl, 1949 based on the presence of two median posterior spines on the pygidium (Ramsköld \& Chatterton 1991). The present specimens are very close to Kettneraspis callicera from the Schoharie Grit and the Onondaga Formation of the New York area described by Whiteley et al. (2002) in the ornament of the cephalon and the length of the posterior spines. Hall \& Clarke (1888) described K. callicera from the limestones of the upper part of the Helderberg Formation in Ontario. Ramsköld \& Chatterton (1991, p. 359, fig. 8) illustrated pygidia of Kettneraspis aracana (Steinmann, 1912) from the Lochkovian Cordillera Real Formation of Bolivia which are very close to the Colombian specimens, although the ornament of the cephalon is different.

\section{Conclusions}

This studied material show the diversity of the trilobites and inarticulate faunas from the Devonian Floresta Formation from Colombia. Sixteen species of trilobites and three species of inarticulate brachiopods are described with a new species in each group: Colombianaspis carvalhoae gen. et sp. nov. and Schizobolus pilasiensis sp. nov. The trilobite and inarticulate faunas permit to point out the presence of two biostratigraphic levels within the Floresta Formation. On the evidence of the trilobites an age range of Late Emsian (serotinus Zone) is assigned to the lower part of the Floresta Formation. Trilobites and inarticulate brachiopods allow to assign a Givetian age to the upper part of this formation.

The faunas show a great similarity with North American forms and implicate unrestricted faunal exchanges between NEAR and Colombia. However certain trilobites show some affinity to South American forms and restricted faunal exchanges were possible with the Malvinokaffric Realm.

\section{Acknowledgements}

Field work in Colombia (Philippe Janvier and Patrick Racheboeuf, together with Carlos Villarroel) was supported by the project "Missions Paléandines" funded by the Fundation Ars Cuttoli-Paul Appell (Fondation de France). The inarticulate brachiopods study (Michal Mergl) was supported by the Grant Agency of the Czech Republic GAČR 205/07/0466: Origin and evolution of the discinoid brachiopods in the Palaeozoic. Pierre Morzadec thanks Maria da Gloria Pires de Carvalho (New York), and David J. Holloway (Melbourne) for their help and fruitful discussions on trilobites. He also thanks Patrick Racheboeuf (Brest) and Carlos Villarroel (Bogotá) for entrusting him with the study of this material. Authors are greatly indebted to Yves Candela (Edinburgh) for correction of the language, to Rémy Gourvennec (Brest) and Hervé Morzadec (Rennes) for the figures and to Greg Edgecombe (London) and Leonid Popov (Cardiff) for constructive reviews.

\section{References}

Adrain, J.M. \& KLOCK, G.J. 1997. Lower Devonian Aulacopleuroidean Trilobites from Oklahoma. Journal of Paleontology 71, 703-712.

Archbold, N.W., Cisterna, G.A. \& Sterren, A.F. 2005. Lingulida (Brachiopoda) from the early Permian of Argentina. Proceedings of the Royal Society of Victoria 117, 307-317.

BALINSKI, A. 1995. Brachiopods and conodont biostratigraphy of the Famennian from the Debnik anticline, southern Poland. Palaeontologia Polonica 54, 1-88.

BALINSKI, A. 1979. Brachiopods and conodonts from the Frasnian of the Debnik anticline, southern Poland. Palaeontologia Polonica 39, 129-136.

Balinski, A. \& Holmer, L.E. 1999. The Late Devonian trematid lingulate brachiopod Schizobolus from Poland. Acta Palaeontologica Polonica 44, 335-346.

BARRANDE, J. 1852. Système silurien du centre de la Bohême. lère partie. Recherches paléontologiques, 1, Trilobites. $935 \mathrm{pp}$. Privately published, Prague \& Paris.

BARRANDE, J. 1872. Système silurien du centre de la Bohême. lère partie. Recherches paléontologiques, V1, Acéphales. 342 pp. Privately published, Prague \& Paris.

Barrett, S.F. 1988. The Devonian System in Colombia, 705-717. In McMillan, N.J., Embry, A.F. \& Glass, D.J. (eds) Devonian of the World, Second International Symposium on the Devonian System Calgary, Canadian Society of Petroleum Geologists Calgary, vol. 1.

BARRETT, S.F. \& IsAaCSON, P.E. 1988. Devonian paleogeography of South America, 655-667. In McMillan, N.J., EMBRY, A.F. \& GLass, D.J. (eds) Devonian of the World, Second International Symposium on the Devonian System Calgary, Canadian Society of Petroleum Geologists Calgary, vol. 1.

Berry, C.M., Morel, E., Mojica, J. \& Villarroel, C. 2000. Devonian plants from Colombia, with discussion of their geological and paleogeographical context. Geological Magazine 137, 257-268. DOI 10.1017/S0016756800003964

Biernat, G. \& EMIG, C. 1993. Anatomical distinctions of Mesozoic lingulide brachiopods. Acta Palaeontologia Polonica 38, 1-20. 
Bosetti, E.P. 1989. Revisao sistemática dos Lingulida (Brachiopoda; Inarticulata) da Formação Ponta Grossa (Devoniano) Estado do Paraná, Brasil. Anais do Congreso Brasileiro de Paleontologia 11, 73-89.

Bosetti, E.P., Grahn, Y., Horodyski, R.S., Mauller, P.M., BreuER, P. \& ZABINI, C. 2011. An earliest Givetian "Lilliput Effect" in the Paraná Basin and the collapse of the Malvinokaffric shelly fauna. Paläontologische Zeitschrift 85, 49-65. DOI 10.1007/s12542-010-0075-8

Bosetti, E.P. \& Quadros, R. 1996. Contribução ao estudo dos Lingulida (Brachiopoda: Inarticulata) da Formação Ponta Grossa, Devoniano, Bacia do Paraná, Município de Chapada dos Guimaras, Mato Grosso, Brasil. Anais do Simpósio Sulamericano do Siluro Devoniano, 357-361.

Boucot, A.J. 1975. Evolution and extinction rate controls. 427 pp. Elsevier, Amsterdam.

Boucot, A.J. \& Racheboeuf, P.R. 1994. Biogeographic summary of the Malvinokaffric Realm, silurian and devonian Fossils, 13-14, 71-75. In Suarez Soruco, R. (ed.) Fossiles y Facies de Bolivia, YPFB.

Boucot, A.J., Rowell, A.J., Racheboeuf, P.R., Pereira, E., Gonçalves de Melo, J.H. \& Peixoto de Siqueira, L. 2001. Position of the Malvinokaffric Realm's northern boundary (Early Devonian) based on newly discovered brachiopods from the Parecis Basin (Brazil). Journal of the Czech Geological Society 46, 109-120.

BruguiÈre, J.G. 1797. Vers, Coquilles, Mollusques et Polypiers. Tableau encyclopédique et méthodique des trois règnes de la nature, vol. 2, pl. 96-314. Agasse, Paris.

BurmeISTER, H. 1843. Die Organisation der Trilobiten aus ihren lebenden Verwandten entwickelt; nebst einer systematischen bersicht aller seither beschreibenen Arten. 147 pp. Reimer, Berlin. DOI 10.5962/bhl.title.9086

CampBell, K.S.W. 1977. Trilobites of the Haragan, Bois d'Arc and Frisco Formations (Early Devonian), Arbuckle Mountains Region, Oklahoma. Oklahoma Geological Survey 123, 1-227.

Carvalho, M.G.P. DE \& FonseCa, V.M.M. DA 2007. The trilobite "Dalmanites" maecurua Clarke, 1890 (Middle Devonian, Amazon Basin, Brazil) and the new genus Amazonaspis (Synphoriidae). American Museum, Novitates 3591, 1-14. DOI 10.1206/0003-0082(2007)3591[1:TTDMCM]2.0.CO;2

Carvalho, M.G.P. De \& Moody, J. 2000. A Middle Devonian Trilobite Assemblage from Venezuela. American Museum, Novitates 3292, 1-15. DOI 10.1206/0003-0082(2000)292<0001:AMDTAF>2.0.CO;2

CASTER, K.E. 1939. A Devonian fauna from Colombia. Bulletin of American Paleontology 24(83), 1-218.

CHAPMAN, E.J. 1890. Some remarks on trilobites as influenced by stratigraphical relations, with outline of a new grouping of these forms. Transactions of the Royal Society of Canada 7, $113-120$.

Clarke, J.M. 1892. On Cordania, a proposed new genus of trilobites. $45^{\text {th }}$ Annual Report of New York State Museum 1891, 440-443.

Clarke, J.M. 1900. Oriskany fauna of Becraft Mountain. New York State Museum, Memoir 3, 1-128.

Clarke, J.M. 1905. Percé: a brief sketch of its geology. Report of the State Paleontologist 1905. New York State Museum 80, 134-172.
Clarke, J.M. 1907. Some new Devonic fossils. New York State Museum, Geology 12(107), 153-291.

Clarke, J.M. 1908-1909. Early Devonic history of New York and eastern North America. New York State Museum, Memoir 9(1), 1-366 pp.; (2), 1-250 pp.

Clarke, J.M. 1913. Fósseis Devonianos do Paraná. Monographias do Servico Geológico e Mineralógico do Brasil 1, $1-353$.

ConRad, T.A. 1841. On the paleontology of the State of New York. Reports of the New York State Geological Survey 39-40, 48-49.

Cooper, G.A. 1942. New genera of North American brachiopods. Journal of the Washington Academy of Sciences 32, 228-235.

Cooper, G.A. \& Dutro, J.T. 1982. Devonian brachiopods of New Mexico. Bulletins of American Paleontology 82 and 83, $1-315,1-215$.

Cooper, M.R. 1982. A revision of the Devonian (Emsian Eifelian) Trilobita from the Bokkeveld Group of South Africa. Annals of the South African Museum 89, 1-174.

COPPER, P. 1977. Paleolatitudes in the Devonian of Brazil and the Frasnian-Famennian mass extinction. Palaeogeography, Palaeoclimatology, Palaeoecology 21, 165-207. DOI 10.1016/0031-0182(77)90020-7

DALL, W.H. 1870. A revision of the Terebratulidae and Lingulidae. American Journal of Conchiology 6, 88-168.

Delo, D.M. 1935. A revision of the Phacopid trilobites. Journal of Paleontology 9, 402-420.

Delo, D.M. 1940. Phacopid trilobites of North America. Geological Society of America, Special Papers 29, 1-135. DOI 10.1130/SPE29-p1

Eвасн, M.C. \& Ahyong, S.T. 2001. Phylogeny of the Trilobite subgenus Acanthopyge (Lobopyge). Cladistics 17, 1-10. DOI 10.1111/j.1096-0031.2001.tb00107.x

Egorov, A.N. \& Popov, L.E. 1990. Novyi rod lingulid in niznepermskikh otlozhenii Sibirskoi platformy. Palaeontologicheskii zhurnal 1990(4), 111-115.

ELDREDGE, N. 1973. Systematics of lower and lower middle Devonian species of the trilobite Phacops Emmrich in North America. Bulletin of the American Museum of Natural History 151, 285-338.

Eldredge, N. \& Branisa, L. 1980. Calmoniid trilobites of the Lower Devonian Scaphocoelia Zone of Bolivia, with remarks on related species. Bulletin of the American Museum of Natural History 165, 181-289.

EldRedge, N. \& Ormiston, A.R. 1979. Biogeography of Silurian and Devonian trilobites of the Malvinokaffric Realm, 147-167. In Gray, J. \& Boucot, A.J. (eds) Historical biogeography, plate tectonics, and the changing environment. Oregon State University Press.

FigueIRAs, A. 1991. Fauna eodevonica del Uruguay. Revista Técnica de YPFB 12, 57-64.

Forero, A.S. 1970. Estratigrafía del Precretácico en el Flanco Occidental de la Serrania de Perijá. Geologia Colombiana 7, $1-77$.

Goryansky, V.Y. \& Popov, L.E. 1985. Morphology, systematic position and origin of the inarticulate brachiopods with calcareous shells. Paleontologicheskii zhurnal 1985(3), 3-14. [in Russian] 
GraY, J.E. 1840. Synopsis of the contents of the British Museum, $42^{\text {th }}$ edition. 370 pp. British Museum, London.

GREEN, J.M. 1832. Synopsis of the trilobites of North America. American Journal of Geology and Natural History 1(12), $558-560$.

HAAS, W. 1968. Trilobiten aus dem Silur und Devon von Bithynien (NW Turkei). Palaeontographica A 130, 60-207.

HaLl, J. 1861. Descriptions of new species of fossils from the Upper Helderberg, Hamilton and Chemung Groups. Advance Sheets of the Fifteenth Annual Report, New York State Cabinet of Natural History, 1-83.

Hall, J. 1863. Description of a new species of Brachiopoda, from the Upper Helderberg, Hamilton and Chemung Groups. New York State Cabinet of Natural History, $16^{\text {th }}$ Annual Report, Albany, 19-37.

Hall, J. 1871. Descriptions of new species of fossils, from the investigations of the Survey. Geological Survey of Wisconsin, Report of the Superintendent, January 1, 1861, 9-52.

Hall, J. \& Clarke, J.M. 1888. Descriptions of the trilobites and other crustacea of the Oriskany, Upper Helderberg, Hamilton, Portage, Chemung and Catskill Groups. Geological Survey of the State of New York, Palaeontology 7, 1-152.

Hall, J. \& Clarke, J.M. 1892. An introduction to the study of the genera of Palaeozoic Brachiopoda. New York Geological Survey, part 1, 1-367.

Hall, J. \& CORDA, A.J.C. 1847. Prodrom einer monographie der böhmischen Trilobiten. Abhandlungen Königlischen böhmischen Gesellschaft der Wissenschaften 5, 1-176.

HavliceK, V. 1984. Diagnoses of new brachiopod genera and species. Part 1, 57-59. In PARIZEK, A., KLeIN, L. \& RÖHLICH, P. (eds) Explanatory booklet, Geological Map of Libya, 1/250 000 (NG 33-1), Sheet Idri. Industrial Research Centre, Tripoli, Libya.

Holloway, D.J. 1981. Silurian Dalmanitacean trilobites from North America, and the subfamilies Dalmanitinae and Synphoriinae. Palaeontology 24, 695-731.

Holloway, D.J. \& Carvalho, M.G.P. DE 2009. The extraordinary trilobite Fenestraspis (Dalmanitidae, Synphoriinae) from the Lower Devonian of Bolivia. Palaeontology 52, 933-949. DOI 10.1111/j.1475-4983.2009.00878.x

Holloway, D.J. \& Carvalho, M.G.P. DE 2010. The trilobite Chacomurus (Dalmanitidae Synphoriinae) from the Lower Devonian of Bolivia. Memoirs of the Association of Australasian Palaeontologists 39, 71-83.

Holmer, L.E. 1991. The systematic position of Pseudolingula Mickwitz and related brachiopods, 15-21. In MAC KInNON, D.I., LEE, D.E. \& CAMPBELL, J.D. (eds) Brachiopods through time. Balkema, Rotterdam.

Holmer, L.E. \& Popov, L.E. 2000. Lingulata, 30-146. In Williams, A., Brunton, C.H.C., CARlson S.J. et al. Treatise on Invertebrate Paleontology, part H, Brachiopoda, Revised, Volume 2. Geological Society of America \& University of Kansas, Boulder \& Lawrence.

JanVier, P. \& Villarroel, C. 2000. Devonian Vertebrates from Colombia. Palaeontology 43, 729-763.

DOI 10.1111/1475-4983.00147

Jell, P.A. \& Adrain, J.M. 2003. Available generic names for trilobites. Memoirs of the Queensland Museum 48, 331-553.
Johnson, J.G. 1970. Taghanic onlap and the end of North American Devonian Provinciality. Geological Society of America $81,2077-2106$. DOI 10.1130/0016-7606(1970)81[2077:TOATEO]2.0.CO;2

Kayser, E. 1880. Dechenella, eine devonische Gruppe der Gattung Phillipsia. Zeitschrift der Deutschen Geologischen Gesellschaft 32, 703-707.

KAYSER, E. 1897. Beiträge zur Kenntniss einiger paläozoischer Faunen Süd-Americas. Zeitschrift der Deutschen Geologischen Gesellschaft 49, 274-317.

Kozlowski, R. 1923. La faune dévonienne de Bolivie. Annales de Paléontologie 12, 1-112.

Lange, F.W. 1943. Novos fósseis devonianos do Paraná. Arquivos do Museu Paranaense 3, 215-231.

LespérAnCE, P.J. 1975. Stratigraphy and Paleontology of the Synphoriidae (Lower and Middle Devonian Dalmanitacean trilobites). Journal of Paleontology 49, 91-137.

LESPÉRANCE, P.J. 1991. Vincular furrows in some early Silurian and Devonian Phacopidae (Trilobita), predominantly from North America. Journal of Paleontology 65, 276-294.

Lespérance, P.J. \& Bourque, P.A. 1971. The Synphoriinae: an evolutionary pattern of Lower and Middle Devonian trilobites. Journal of Paleontology 45, 182-208.

LesPérAnCE, P.J. \& SHEehAn, P.M. 1988. Faunal assemblages of the Upper Gaspé Limestones, Early Devonian of eastern Gaspé, Quebec. Journal Canadien de Sciences de la Terre 25, 1432-1449. DOI 10.1139/e88-137

Lieberman, B. \& KLOC, G. 1997. Evolutionary and Biogeographic patterns in the Asteropyginae (Trilobita, Devonian) Delo, 1935. Bulletin of the American Museum of Natural History $232,1-127$.

LinSLEY, D.M. 1994. Devonian Paleontology of New York containing the brachiopods, bivalves, rostroconchs, gastropods, tergomyans, ammonoids, trilobites, eurypterids and phyllocarids... based on the lithographs of J. Hall \& J. Clarke. Paleontological Research Institution Special Publication 21, $1-472$.

Ludvigsen, R. 1979. Fossils of Ontario: The Trilobites. Ontario Museum, Life Sciences, Miscellaneous Publications, 1-96.

Ludvigsen, R. 1987. Reef trilobites from the Formosa Limestone (Lower Devonian) of southern Ontario. Canadian Journal of Earth Sciences 24, 676-688. DOI 10.1139/e87-066

Maksimova, Z.A. 1972. New Devonian trilobites of the Phacopoidea. Paleontologicheskii zhurnal 1, 88-94.

MENDES, J.C. 1961. Langella, novo gênero de Lingulídeo da série Tubarão. Boletim da Universidade do Paraná, Instituto de Geologia 5, 1-8.

Mendes-Alzola, R. 1934. Contribución al conocimiento de la Fauna Devónica de Rincón de Alonso. Instituto de Geología y Perforaciones, Boletín 21, 21-54.

Mendez-AlzolA, R. 1938. Fósiles Devónicos del Uruguay. Instituto de Geología y Perforaciones, Boletín 24, 1-115.

Mendez-Alzola, R. \& Sprechmann, P. 1971. Algunas orbiculoideas devonicas de la Precordillera de San Juan, Rep. Argentina. Revista de la Asociación Geológica Argentina 24, $517-525$.

MenKe, C.T. 1828. Synopsis methodica molluscorum generum omnium et specierum earum quae in Museo Menkeano adservantur. 91 pp. G. Uslar, Pyrmonti. 
Morales, P.A. 1965. A contribution of the knowledge of the devonian Faunas of Colombia. Universidad Industrial de Santander (Colombia). Boletin de Geologia 19, 51-109.

Morzadec, P. 1969. Le Dévonien de la rive nord de la rivière du Faou (Finistère). Bulletin de la Société géologique et minéralogique de Bretagne, 1-58.

Morzadec, P. 1983. Trilobites du Dévonien (Emsien-Famennien) de la rade de Brest (Massif armoricain). Palaeontographica A 181, 103-184.

Ormiston, A.R. 1972. Lower and Middle Devonian trilobite zoogeography. Northern North America. Proceedings $24^{\text {th }}$ International Geological Congress, section 7, 594-604.

Owens, R.M. 1973. British Ordovician and Silurian Proetidae (Trilobita). Monographs of the Palaeontographical Society 535, 1-98.

ÖZDikMEN, H. 2009. Nomenclatural changes for twenty trilobites genera. Munis Entomology \& Zoology 4(1), 155-171.

PhLEger, F.B. 1936. Lichadian trilobites. Journal of Paleontology 10, 593-615.

Prantl, F. \& Přibyl, A. 1949. A study of the Superfamily Odontopleuracea nov. superfam. (Trilobites). Rozpravy Ústředního ústavu geologického ČSR 12, 1-221.

Prantl, F. \& PřIBYL, A. 1951. Revise čeledi Otarionidae R. \& E. Richter z českého siluru a devonu (Trilobitae). Sborník Ústředního ústavu geologického ČSR, Oddíl paleontologický 17, 353-512.

P̌̌ıBYL, A. 1946. O několika nových trilobitových rodech z českého siluru a devonu. Př́roda (Brno) 38(5-6), 89-95.

PřibYl, A. \& ERben, H.K. 1952. Uber einige neue order wenig bekannte Acanthopyginae (Tril.) des böhmischen und des deutschen Devons. Paläontologische Zeitschrift 26, 141-174. DOI 10.1007/BF03224495

RAMSKÖLD, L. \& CHATTERTON, B.D. 1991. Revision and subdivision of the polyphyletic "Leonaspis" (Trilobita). Transactions of the Royal Society of Edinburgh, Earth Sciences 82, 333-371. DOI 10.1017/S026359330000420X

RAMSKÖLD, L. \& WERDELIN, L. 1991. The phylogeny and evolution of some Phacopid Trilobites. Cladistics 7, 29-74. DOI 10.1111/j.1096-0031.1991.tb00021.x

Richter, R. \& Richter, E. 1950. Arten der Dechenellinae (Tril.). Senckenbergiana lethaea 31, 151-184.

Schuchert, C. 1893. Classification of the Brachiopoda. American Geologist 11, 141-167.

Steinmann, G. 1912. Beitrage zur Geologie und Paläontologie von Südamerica, 176-252. In Steinmann, G. \& Hoeck, H. Das Silur und Cambrium des Hochlandes von Bolivia und ihre Fauna. Neues Jahrbuch für Geologie und Paläontologie 34.

Stumm, E.C. 1953. Trilobites of the Devonian Traverse Group of
Michigan. Contributions from the Museum of Paleontology, University of Michigan, Ann Arbor X (6), 101-157.

Stumm, E.C. 1954. Lower Middle Devonian Phacopid Trilobites from Michigan, Southwestern Ontario, and the Ohio Valley. Contribution from the Museum of Paleontology, University of Michigan, Ann Arbor XI (11), 201-221.

SuAREZ-Soruco, R. 1971. Tarijactinoides jarcasensis n. gen. $\mathrm{n}$. sp. del Devónico inferior. Boletin del Servicio Geológico de Bolivia 15, 53-56.

Thomas, A.T. \& Holloway, D.J. 1988. Classification and phylogeny of the trilobite order Lichida. Philosophical Transactions of the Royal Society of London, B - Biological Sciences 321(1205), 179-262. DOI 10.1098/rstb.1988.0093

Ulrich, E.O. 1886. Description of new Silurian and Devonian fossils. American Paleontology, Contributions 1, 3-35.

Vaccari, N.E., Waisfeld, B.G. \& Edgecombe, G.D. 1994. Calmoniid trilobites of the Lower Devonian Scaphocoelia Zone in Argentine Precordillera. Geobios 27(5), 591-608. DOI 10.1016/S0016-6995(94)80257-2

VANUXEM, L. 1842. Geology of New York. Part 3, comprising the survey of the third geological district. Natural History of New York (4, 3). 306 pp. D. Appleton \& Co., New York.

Vogdes, A.W. 1890. A bibliography of Paleozoic Crustacea from 1698 to 1889 including a list of North American species and a systematic arrangement of genera. United States Geological Survey, Bulletin 63, 1-177.

WaAgen, W. 1885. Salt Range fossils, I. Productus-Limestone fossils, Brachiopoda. Memoirs of the Geological Survey of India, Palaeontologica Indica, (series 13) 4(5), 729-770.

Whiteley, T.R., KLOC, G. \& BRETT, C.E. 2002. Trilobites of New York: An Illustrated Guide. 456 pp. Cornell University Press.

Whittington, H.B. 1956. Type and other species of Odontopleurridae (Trilobita). Journal of Paleontology 30, 504-520.

Whittington, H.B. 1960. Cordania and other trilobites from the Lower and Middle Devonian. Journal of Paleontology 34, 405-420.

Wolfart, R. 1968. Die Trilobiten aus dem Devon Boliviens und ihre Bedeutung für Stratigraphie und Tiergeographie. Geologisches Jahrbuch, Hannover 74, 1-202.

Zabini, C., Bosetti, E.P., Horodyski, R.S. \& Marsumura, W.M.K. 2007. Lingulídeos: revisão dos conceitos morphoanatômicos, fisiólogicos, reproductivos, paleo-ecologicos e a importância do grupo no Devoniano de regiao dos Campos Gerais do Paraná, Brasil. Revista Terra Plural 1, 123-141.

Zabini, C., BosetTi, E.P. \& Holz, M. 2010. Taphonomy and taphofacies analysis of lingulid brachiopods from Devonian sequences of the Paraná Basin, Brazil. Palaeogeography, Palaeoclimatology, Palaeoecology 292, 44-56.

DOI 10.1016/j.palaeo.2010.03.025 